Pamiętnik Literacki 2014, 2, s. 21-45
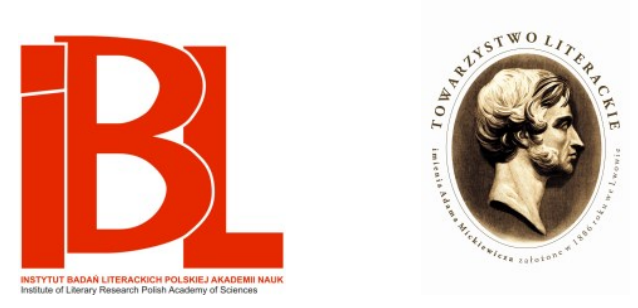

„Szanfary”

Raz jeszcze o przekładach Adama

Mickiewicza i Ludwika Spitznagla

Paweł Siwiec 
Pamiętnik Literacki CV, 2014, z. 2, PL ISSN 0031-0514

PAWEŁ SIWIEC Uniwersytet Jagielloński, Kraków

\section{„SZANFARY” RAZ JESZCZE O PRZEKŁADACH ADAMA MICKIEWICZA I LUDWIKA SPITZNAGLA}

Pod koniec lat dwudziestych XIX w. Adam Mickiewicz, Juliusz Słowacki oraz serdeczny przyjaciel autora Kordiana, Ludwik Spitznagel, niezależnie od siebie postanowili przybliżyć polskiemu czytelnikowi arabską kasydę zatytułowana Lāmiyyat $a l^{-} A r a b^{1}$. Utwór ten, którego autorstwo przypisywane jest poecie przedmuzułmańskiemu zwanemu Aš-Šanfarā ${ }^{2}$, to jeden $z$ najbardziej rozpoznawalnych staroarabskich poematów. Sam zaś Aš-Šanfarā - choć w ciągu ostatnich kilkunastu wieków powstało o nim wiele prac - to postać, co do której do końca nie wiadomo, ile prawdy, a ile mitu w sobie kryje ${ }^{3}$. Nie ma też całkowitej pewności, czy Lāmiyyat $a l^{-} A r a b$, tak jak wiele innych przekazywanych najpierw drogą ustna, a dopiero później spisanych staroarabskich wierszy, należy rzeczywiście do literackiej spuścizny tego właśnie autora ${ }^{4}$. O ile Mickiewicz i Spitznagel postawili sobie za cel

1 Ar. "lāmiyya” oznacza wiersz, w którym zasadniczym komponentem monorymicznych klauzul wersowych jest spółgłoska „lām” (l). Takich wierszy w średniowiecznej poezji arabskiej było mnóstwo, jednak z niewiadomych powodów tylko lāmiyya Aš-Šanfary obdarzona została mianem kasydy Arabów.

2 Według przeważającej opinii Aš-Šanfarā (dosł. „grubousty”) było przezwiskiem lub przydomkiem poety. Jego prawdziwe imię to Tābit Ibn Aws lub ${ }^{\mathrm{c} A m r}$ Ibn Barrāq bądź Tāābit Ibn Ğābir - nie ma co do tego jednomyślności (zob. Dīwān aš-Šanfarā. I'dād wa-taqdīm Țalāl Ḥa rb. Bayrūt 1996, s. 25. - Dīwān aš-Šanfarā. Ğama ${ }^{\mathrm{c} a}-h u$ wa-ḥaqqaqa-hu wa-šaraḥa-hu Im̄̄l $\mathrm{B}$ a dī $\bar{i}^{\mathrm{c}} \mathrm{Ya}^{\mathrm{c}} \mathrm{qu} \mathrm{u} b$. Bayrūt 1996, s. 9). Poeta zaliczany jest do grupy „rozbójników” lub „włóczęgów” (ar. „aṣ-șacālīk”). Czas jego śmierci syryjski historyk Hayr ad-Dīn az-Zarkalī (1893-1973) określił w pracy Al-Aclām (t. 5. Bayrūt 1980, s. 85) na ok. 70 rok przed hidżrą (ucieczką Mahometa z Mekki w 622 r. n.e.), jednak jako datę kalendarza gregoriańskiego podał omyłkowo rok 525 n.e. zamiast 552 i odtąd błąd ten powielany jest bezkrytycznie w wielu publikacjach.

3 Zgodnie $\mathrm{z}$ najbardziej rozpowszechnionym przekazem Aš-Šanfara wzięty został jako dziecko w niewolę, a następnie, wymieniony na inną osobę, trafił do plemienia As-Salamān, gdzie przygarnięto go jak swojego. Upokorzony i spoliczkowany przez córkę swego opiekuna, nie godzącą się uznać w nim brata, poprzysięga zemstę i odchodzi, odgrażając się, że nie spocznie, póki nie zabije 100 członków plemienia As-Salamān. Pozbawiwszy życia 99 osób, sam zostaje osaczony i zabity. Po jakimś czasie o jego porzuconą na pustyni czaszkę rani się jeden z członków plemienia i w następstwie tego umiera na gangrenę. W ten sposób wypełnia się złożona przez Aš-Šanfarę przysięga. Zob. Abū al-Farağ al-Ișfahānī, Al-Ag̉ānī. T. 21. Tahqịq 'Abd al-Karīm Ibrāhīm al-' 'Izbāwī, Maḥmūd Muḥammad Ganīm. Al-Qāhira 1993, s. 179-195. - J. Georg, Schanfarà-Studien. T. 1-2. München 1914-1915. - Encylopedia of Islam. T. 9. Leiden 1997, s. 301-303.

4 Filolog Abū ${ }^{\mathrm{c}} \mathrm{Alī}$ al-Q $\mathrm{a}{ }^{1} \bar{i}$ (893-967) przytacza w Al-Amālì (t. 1. Bayrūt, b.r., s. 156) słowa 
dokonanie poetyckiego przekładu owego utworu, o tyle Słowacki stworzył własny poemat, będacy parafrazą niewiele mającą wspólnego $\mathrm{z}$ oryginałem ${ }^{5}$.

Od roku 1806 kasyda ta - w wersji oryginalnej wraz $\mathrm{z}$ francuskim tłumaczeniem filologicznym i dodatkowymi objaśnieniami - stała się dostępna dla czytelnika europejskiego dzięki wydanej przez Silvestre’a de Sacy'ego chrestomatii tekstów arabskich ${ }^{6}$. Mieli więc sposobność zapoznać się z nią, a także $z$ legendą Aš-Šanfary, działający zarówno na uniwersytecie wileńskim, jak i petersburskim polscy orientaliści oraz obracajacy się wówczas w ich środowisku zafascynowani Orientem nasi romantycy.

Postać zbuntowanego, trawionego poczuciem krzywdy i żądzą zemsty banity $\mathrm{z}$ wyboru, który - przedkładając towarzystwo dzikich zwierząt nad obcowanie z ludźmi - wędruje przez pustkowia Arabii, wymierzając własnoręcznie sprawiedliwość, bardzo dobrze odpowiadała cechom bohatera romantycznego. Ponadto urzekała egzotyka surowych obrazów malowanych słowami staroarabskiego poety. Wszystko to sprawiało, że utwór niemal sam narzucał się do tłumaczenia ${ }^{7}$.

Mickiewicz oparł się głównie na francuskim przekładzie de Sacy’ego, a następnie korygował tekst, korzystając $z$ tłumaczenia dosłownego oraz z komentarzy znanego wówczas orientalisty Józefa Sękowskiego ${ }^{8}$, o czym sam wspomina w przypisie do swojego przekładu kasydy ${ }^{9}$. Z kolei Spitznagel, cieszący się sławą niezwykle utalentowanego poligloty i znawcy języków wschodnich, w tym - arabskiego, tłumaczyć miał bezpośrednio $z$ oryginału. Wydaje się wszakże mało prawdopodobne, by nie sięgną też do wersji de Sacy’ego, zwłaszcza że Chrestomathie arabe była jednym $z$ podstawowych podręczników w Instytucie Języków Wschodnich uniwersytetu petersburskiego, gdzie Spitznagel studiował ${ }^{10}$. Każdemu z tych przekładów

swojego mistrza, Ibn Durayda (837-934), iż kasyda ta jest autorstwa Halafa al-Ahmara (zm. ok. 796), znanego recytatora i przekaziciela poezji rodem z Basry. Na ten temat zob. też Y ùs uf Hu u la y y if, $A \check{s}$-šu $u^{c} a \bar{a}^{\supset}$ aș-șa ālīk fì al- ${ }^{c}$ așr al-ğāhilī. Al-Qāhira 1966, s. 330-338. - S. Pin c kn e y Stetkevych, Archetype and Attribution in Early Arabic Poetry: al-Shanfara and the Lamiyyat al-Arab. „International Journal of Middle East Studies” 1986, nr 3. - W. M a n s o u r, The Reality beyond the Hyperbolic Accentuation of Self in Al-Shanfarā's Poem „Lāmiyyatu'l 'Arab”. „Journal of Near Eastern Studies" 2005, nr 4.

5 Jak już w pierwszej połowie ubiegłego stulecia zauważył J. Kl e in e r (Słowacki. Lwów 1938, s. 25): „Z istotnej opowieści arabskiej sławiącej jego [tj. Aš-Šanfary] czyny, którą i Mickiewicz przełożył i (według relacji Słowackiego) Spitznagel, nic nie zostało prócz imienia i prócz zabarwienia muzułmańsko-orientalnego".

6 S. de Sa cy, Chrestomathie arabe. T. 1-3. Paris 1806; wyd. 2, popr.: Paris 1826.

7 Zwracali na to uwage m.in.: J. Bi elaw s ki, Historia literatury arabskiej. Wrocław 1968, s. 37. - K. Ska ṙ̇yńs ka - B o c h eń s k a, Honor i zemsta. Arabskie wpływy w poezji Adama Mickiewicza. „As-Sadaka” 1982, nr 13. - M. D zi e k a n, Aš-Šanfarā romantyczny. W zb.: Orientalizm romantyczny. Arabski romans rycerski. Warszawa 1997, s. 54-57. Literatura arabska: dociekania i prezentacje. T. 1 .

8 Józef Sękowski (1800-1858), tłumacz z literatury arabskiej (m.in. Bajki mędrca Lokmana) i perskiej (Pieśni Hafiza), od 1822 r. przez 25 lat kierował katedrą języków wschodnich na Uniwersytecie Petersburskim; wcześniej przez dwa lata przebywał na Wschodzie (m.in. w Stambule, Bejrucie, Damaszku, Aleksandrii, Kairze).

9 A. Mickiewicz, Wybór poezyj. Oprac. Cz. Zgorzelski. T. 2. Wyd. 4, przejrz. Wrocław 1997, s. 175 . BN I 66.

10 Zob. W. D e r e j c zy k, Ludwik Spitznagel: przyjaciel Juliusza Słowackiego. Uzup. R. Le s z c z y ńs ki. Warszawa 1994, s. 27. 
nadany też został identyczny tytuł: Szanfary ${ }^{11}$, nawiązujący wprost do imienia bohatera utworu.

Poetyckim przekładom Lāmiyyat al-cArab na język polski poświęcono dość sporo miejsca ${ }^{12}$. Pisano o okolicznościach towarzyszacych ich powstawaniu, formułowano sądy na temat walorów artystycznych, oceniano stopień zgodności z francuskim tłumaczeniem de Sacy’ego. Na długie lata utrwaliła się opinia, że przekład Spitznagla góruje nad Mickiewiczowskim. Do jej rozpowszechnienia w dużym stopniu przyczyniła się subiektywna i bardzo emocjonalna ocena Słowackiego, który przekład ten przechowywał niemal jak relikwię ${ }^{13}$. Na niekorzyść Mickiewicza przemawiała też nieznajomość arabskiego, a więc tłumaczenie $z$ drugiej ręki.

W tym miejscu warto zwrócić uwagę, że Spitznagel - nie ujmując nic jego niepospolitym zdolnościom lingwistycznym - uczył się arabskiego, a także innych języków orientalnych w ramach zaledwie 3-letniego kursu uniwersyteckiego. To stanowczo za mało, by z powodzeniem zmierzyć się z tekstem poetyckim stworzonym w średniowiecznej arabszczyźnie, podobnej do tej, w jakiej powstał Koran. Z tekstem, który już na przełomie IX i X w. wymagał objaśnień filologów i antologistów arabskich $^{14}$. Tak więc Spitznagel albo miał, podobnie jak de Sacy, dostęp do bliżej nie znanych arabskich rękopisów zawierających komentarze do kasydy Aš-Šanfary ${ }^{15}$ (co raczej należy wykluczyć), albo też (i to jest najbardziej prawdopodobne), podpierając się swoją znajomością arabskiego, konfrontował zamieszczone w Chrestomathie arabe de Sacy'ego dwie wersje kasydy: tekst arabski oraz jego dosłowne tłumaczenie na francuski.

Próbę bezstronnej oceny obu przekładów - ciąle jednak w porównaniu $z$ wersją francuską - podją dopiero Czesław Bobolewski ponad 100 lat od samobójczej śmierci Spitznagla. W sposób bardzo lapidarny, na niespełna czterech stronicach, wykazał ich plusy i minusy, stawiając jednak wyżej tłumaczenie Mickiewicza. Spitznaglowi wytknął młodzieńczą powierzchowność i niedbalstwo $\mathrm{w}$ formie ${ }^{16}$. Pisał m.in.:

Mickiewicz często zmienia lub rozszerza obrazy (tendencją stała jest tu nadawanie ruchu i konkretyzowanie), wybiera lub opuszcza pewne rzeczy, stara się dodać im kolorytu lokalnego, używając terminów i zwrotów, które sam w przypisach objaśnia, niemniej stara się zachować komplet myśli, choć

11 Taki właśnie zapis imienia arabskiego poety jest spolszczeniem francuskiego „Schanfari”. Wskazywałoby to, że zarówno Mickiewicz, jak i Spitznagel korzystali z pierwszego wydania chrestomatii de Sacy’ego, co zauważył już R. Pilat (Geneza „Farysa”. „Pamiętnik Towarzystwa Literackiego imienia Adama Mickiewicza” 1888, s. 127). W drugim, poprawionym wydaniu z 1826 r. występuje już Schanfara - zgodnie z arabskim brzmieniem. Przekład Mickiewicza oraz parafraza Słowackiego opatrzone zostały dodatkowo podtytułami: Kasyda z arabskiego oraz Ułomki poematu arabskiego. Zob. np. Cz. B o b ole w s ki, Ze spuścizny rękopiśmiennej Ludwika Władysława Spitznagla. W zb.: Księga pamiątkowa Koła Polonistów słuchaczów Uniwersytetu Stefana Batorego w Wilnie. 19221932. Wilno 1932. - De r e j c zy k, op. cit. - D z i e k a n, op. cit. (w swym artykule autor przytoczył we własnym tłumaczeniu na język polski fragment Al-Ag்āni Al-Iṣfahānīego zawierający biografię Aš-Šanfary).

13 Zob. Derej czyk, op. cit., s. 26.

14 Autorami najstarszych znanych komentarzy filologicznych do Lämiyyat al- ${ }^{c}$ Arab sa Al - M u b a rrid (826-898), Ib n Durayd (837-934), Az-Za maȟšarī (1074-1144).

15 De Sa cy, jak sam pisze (op. cit. 〈1826〉, t. 2, s. 350), wykorzystał dwa manuskrypty: jeden znajdujący się w ówczesnej Bibliotheque du Roi (nr 1455) i drugi w Bibliotece Watykańskiej (nr 364). B obolews ki, op. cit., s. 210-213. 
ich porządek i dosłowność stanowią dlań sprawę drugorzędną. Stale ma przy tym dążność do obcinania powtórzeń i dłuższych omówień, do opanowywania swobodniejszej opowieści prozy.

Przekład Spitznagla nie nosi tych cech, - nie widać w nim nawet dążenia do osiągnięcia wierności. [...]

[...]

Również w dbałości o egzotyzm w obrazowaniu, nastrojach, charakterystyce, obyczajowości, tle przekład Spitznagla musi ustąpić Mickiewiczowskiemu. - O ile dodatki Mickiewicza, jak wspomniano, dążą do wzmocnienia tego elementu egzotycznego, o tyle u Spitznagla wnoszą elementy prawie zupełnie egzotyzmu pozbawione [...].

Szanfary więc Mickiewicza w treść jest bogatszy, każdy jego zwrot, niemal słowo jest symbolem dłuższego omówienia oryginału francuskiego, nie zawsze nawet jest dość jasny bez niego ${ }^{17}$.

Do tej pory nie została podjęta próba porównania tych przekładów w zestawieniu $\mathrm{z}$ oryginałem arabskim ${ }^{18}$, choć od samego początku wszyscy wypowiadający się na ten temat wskazują zgodnie na taką potrzebę. Celem piszącego te słowa jest więc wypełnienie owej luki. W analizie pominięty zostanie Szanfary Słowackiego, ponieważ - jak już wspomniano - trudno uznać go za przekład.

Kasyda Lāmiyyat al- ${ }^{c}$ Arab skomponowana została w oparciu o najchętniej stosowane w średniowiecznej poezji arabskiej 8-stopowe metrum o nazwie aț-țawĩ ${ }^{19}$ (czyli „długie”). Jest to utwór w pełni średniówkowy, monorymiczny o proparoksytonicznych klauzulach. Przekład Mickiewiczowski zawiera 154 wersy 13-zgłoskowe o rymach parzystych ze średniówką po siódmej sylabie; tekst podzielony jest arbitralnie na nieregularnej długości stance tematyczne. Tłumaczenie Spitznagla, również podzielone na nieregularnej długości stance, jest niepełne - składa się z 92 wersów, obejmując nieco ponad połowę kasydy. Jest przy tym metrycznie niejednolite - zdecydowana większość wersów to 11-zgłoskowce ze średniówką po piątej sylabie, ale są też nierównomiernie rozłożone 10-zgłoskowce (15 wersów), 13-zgłoskowce (19 wersów) oraz jeden wers 8-zgłoskowy. Rozmieszczenie rymów również nie jest stałe. Odnosi się wrażenie, jakby to była jeszcze wersja robocza.

Jak wygląda to na płaszczyźnie tekstu, pokazuje przedstawiona tu analiza ${ }^{20}$.

Ibidem, s. 211-212.

Porównania Mickiewiczowskiego przekładu z francuskim tłumaczeniem filologicznym de Sacy'ego podjął się W. Bruchnalski (w: A. Mickiewicz. Dzieła. T. 2. Lwów 1900, s. 513-517). Kilka krytycznych uwag na ten temat zamieścił także J. Kleiner w swoim studium o twórczości wieszcza (Mickiewicz. T. 2, cz. 1. Wyd. 2, popr. Lublin 1997, s. 149-152).

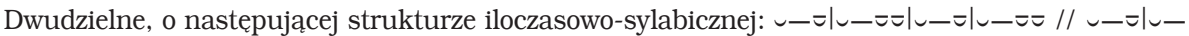

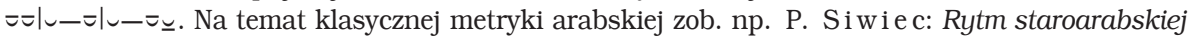
kasydy. Kraków 2005; Zarys poetyki klasycznego wiersza arabskiego. Kraków 2008.

Pod oryginalnym zapisem arabskim podaję transkrypcję, poniżej tłumaczenie filologiczne, a następnie przekłady Mickiewicza i Spitznagla. Ze względu na długość arabskiego wersu oraz w celu wyraźnego zaznaczenia średniówki hemistychy w transkrypcji zapisywane są w osobnych linijkach. W tekście arabskim (również w transkrypcji), zgodnie z ówczesną ortografią, brak jest znaków przestankowych, jednak tłumaczenie filologiczne podporządkowane zostało regułom polskiej interpunkcji. Dla ułatwienia nazwy własne zapisane zostały w transkrypcji dużą literą, mimo że pismo arabskie nie zna majuskuły.

Tekst arabski kasydy przytoczony został za de Sacym (op. cit. 〈1806〉, t. 1, s. 311-321), po zweryfikowaniu na podstawie współczesnego wydania poezji Aš-Š anfa ry (Dīwān aš-Šanfara $\left\langle\right.$ Ğamaca-hu wa-ḥaqqaqa-hu wa-šaraḥa-hu Im $\overline{1} l \mathrm{~B}$ a di $\left.\bar{i}^{\mathrm{c}} \mathrm{Ya}^{\mathrm{c}} \mathrm{q} \mathrm{u} \mathrm{b}\right\rangle$, s. 58-73; dalej odsyłam do 


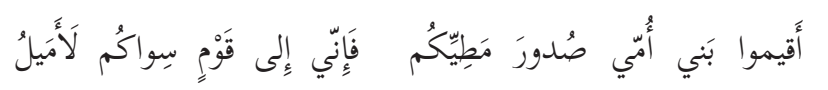

1) aqūmū banī umm-ī șudūra mațiyyi-kum

fa-in-nì ilā qawmin siwā-kum la-amyalu

Tłumaczenie filologiczne:

1) Synowie mej matki! Miejcie baczenie [ocknijcie się, uważajcie, bądźcie gotowi], bo ja do innych niż wy ludzi [ludzi wam obcych] wszak zmierzam [odchodzę].

A. M.

Bracia moi! postawcie wielblądy na nogi,

Dzisiaj Szanfary od was jedzie między wrogi;
L. S.

Dzieci mej matki, gotujcie się w drogę Już z wami dłużej przebywać nie mogęe.

Metonimiczne „banī umm-ī [synowie mej matki]” użyte zostało prawdopodobnie nie tylko ze względów metrycznych (wypełnia w całości drugą stopę: ----), ponieważ wyraz „matka”, na który pada akcent, wzmacnia ładunek emocjonalny słów podmiotu lirycznego. W tym fragmencie L. S. jest więc bliższy wersji oryginalnej. Wyrażenie „aqūmū șudūra mațiyyi-kum” (dosł. „postawcie piersi waszych wierzchowców") jest zwrotem idiomatycznym o znaczeniu "baczcie, ocknijcie się, uważajcie, bądźcie gotowi'. Tłumaczenie A. M. jest zatem niemal dosłowne ${ }^{21}$. Natomiast przekład L. S. zgadza się z wymową oryginału tylko w części pierwszej (,gotujcie się"), ponieważ w tekście arabskim Aš-Šanfarā nie ponagla innych do drogi, lecz sam odchodzi, rozgłaszając o tym wkoło.

Wyrażenie „między wrogi” użyte przez A. M. nie ma odpowiednika w oryginale - mowa tam tylko o innych, obcych ludziach, którzy niekoniecznie musieli być wrogami. Przekład drugiego hemistychu w wykonaniu L. S. jest zupełnie dowolny - choć z drugiej strony, jak wynika z narosłej wokół postaci Aš-Šanfary legendy, przyczyna jego odejścia miało być rzeczywiście rozgoryczenie i złość w stosunku do ludzi, wśród których wzrastał.

$$
\text { فَقَد حُمَّت الحاجاتُ و اللَيلُ مُقِمرِّر وَشُدَّت لِطِيّاتٍ مَطايا وَأَرُحلُ }
$$

2) fa-qad hummati l-hāăḡătu wa-l-laylu muqmirun wa-šuddat li-țiyyātin mațāyā wa-arḥulu

Tłum. fil.:

2) Już sprawy zostały przesądzone [los już o wszystkim rozstrzygnałł], a noc jest księżycowa, ku celom podróży wierzchowce i kulbaki zostały przytroczone.

A. M.

Gotowe juki rzemień do garbów przycisną:

Dalej w drogę, noc ciepła i księżyc zabłysnął.
L. S.

Już siodło ciśnie karki wielbłąda, Już jasny księżyc zza chmury wygląda.

tego właśnie wydania); nieliczne rozbieżności zasygnalizowane tu zostały w przypisach. Tłumaczenie Mickiewicza pochodzi z: Wybór poezyj, t. 2, wyd. 4, s. 174-182), natomiast przekład Spitznagla - z artykułu B obolew ski e go (op. cit., s. 218-220). Ponieważ w analizie konieczne jest częste odwoływanie się do Mickiewicza oraz Spitznagla, zamiast przytaczania ich nazwisk w całości - nużącego dla czytelnika - stosuję inicjały: A. M. i L. S.

21 W przypisie do swego tłumaczenia Mickiewicz (Wybór poezyj, t. 2, wyd. 4, s. 175) napisał: „W oryginale "Podnieście piersi wielbłądów". Jednak użyte w tekście arabskim „mațiyya” ma szerszy zakres - oznacza nie tylko wielbłąda, ale każde dosiadane zwierzę, a więc również konia, muła i osła. 
W przeciwieństwie do przekładów obu poetów wersja oryginalna jest bardzo oszczędna w słowach. Nie zawiera opisu scenerii towarzyszacej przygotowaniom do nocnej wyprawy - nie ma tam juków, garbów, karków wielbłądów i chmur na niebie. Frazę „noc jest księżycowa” w tekście arabskim należy rozumieć przenośnie - że wszystko jest jasne (jasne jak księżyc). Decyzja o odejściu jest nieodwracalna.

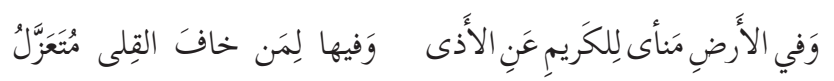

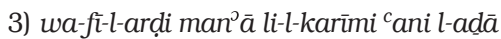
wa-fì-hā li-man hăafa l-qilā mutacazzalu

Tłum. fil.:

3) Na ziemi dla szlachetnego jest ustronie [odległe miejsce] przed krzywdą i na niej [na owej ziemi] dla tego, kto lęka się nienawiści, jest [znajdzie się] odosobnienie.

A. M.

Dalej - jeśli przed skwarem na ziemi są cienie, Dla mężnego przed hańbą znajdzie się schronienie;
L. S.

Jest gdzieś na ziemi kraina daleka, Tam człek przed krzywdą uchronić się może, Tam nieprzystępny dla oka człowieka, Znienawidzoną głowę mą położę.

W interpretacji A. M. pierwsza połowa wersu potraktowana została $z$ dużą swobodą; odległa krainę zastąiło, będące kontynuacją poprzedniego wersu, imperatywne „Dalej”, a zamiast schronienia przed krzywda jest mowa o cieniach przed skwarem. W drugim zaś hemistychu ar. „qilā [nienawiść]” zastapione zostało „hańba”, a "mutacazzalu [odosobnienie]” przetłumaczono jako „schronienie”. Pojawiło się też wyrażenie „Dla mężnego”, nawiązujące do „li-l-karìmi [dla szlachetnego]” z poprzedniego hemistychu.

Przekład L. S. jest bardziej rozbudowany; na każdy hemistych arabski przypadają dwa wersy polskie. Pierwsza połowa tego fragmentu oddaje dokładnie treść tekstu arabskiego (L. S. zrezygnował tylko z przymiotnika „karīm [szlachetny, szczodry]”. Jednak dalsza część jest już bardzo dowolna.

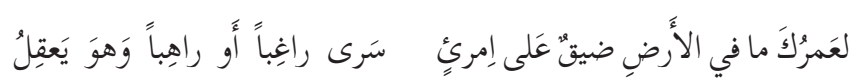

4) $l a^{-}{ }^{c}$ amru-ka mā fì l-arḍi dìqun ${ }^{c} a l a \overline{~ m r i}{ }^{\top}$ in sarā rāgiban aw rāhiban wa-hwa ya qilu

Tłum. fil.:

4) Na życie twe! Nie ma na ziemi niedogodności [przeszkód, uciażliwości, sytuacji bez wyjścia] dla człowieka [mężczyzny], który wędruje [nocal z własnej chęci lub ze strachu, rozsądnym będąc.

$$
\text { A. M. }
$$

I nie będzie mu ciasno, jeśli przy rozumie Gonić rozkosz a zgubie wymykać się umie.
L. S.

Ziemia nie ciasna dla śmiałej istoty, Co chwil północnych dobrze umie użyć, By ścigać lube swej żądzy przedmioty, Lub krwawym zemsty zamiarem usłużyć.

I tym razem L. S. potrzebował dwukrotnie więcej przestrzeni wierszowej. Jednocześnie znowu znacznie oddalił się od wersji arabskiej. Przekład A. M., choć również dość swobodny, bliższy jest oryginałowi, tak co do treści, jak i co do formy. Ciekawe, że u obu poetów ar. „dīqun” przetłumaczone zostało dosłownie 
jako „ciasno” lub „ciasna”, zgodnie z etymologicznie pierwszym sensem tego słowa $^{22}$.

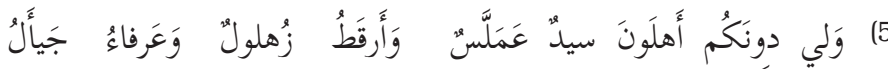

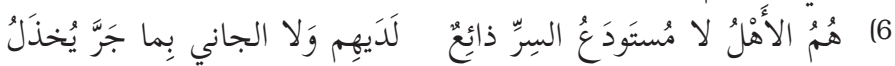

5) wa-lī dūna-kum ahlūna sīdun 'amallasun wa-arqațu zuhlūlun $w a^{-}{ }^{c} a r f \bar{a}^{\supset} u$ ğay ${ }^{\supset} a l u$

6) humu l-ahlu lā mustawdacu s-sirri $\underline{d} \bar{a}^{\top} i^{c} u n$ laday-him wa-lā l-ğānī bi-ma ğarra yuḥdalu

Tłum. fil.:

5) Mam ja innych [obcych wam] pobratymców - mocnego i szybkiego wilka, lamparta o gładkiej sierści i hienę długogrzywą.

6) Oni są [prawdziwą] rodziną, żaden sekret się nie wyda im powierzony, a tego, kto występku się dopuści, nie odtrącą.

$$
\text { A. M. }
$$

Znajdę ja druhów, których przyjaźń więcej warta: Znajdę płowego wilka i pstrego lamparta, Hyjenę, zdobycz kroki pędzącą chromymi. To moi przyjaciele, - nie masz między nimi Półgłówka, co mu tajnia w ustach nie doleży, Co brata błądzącego z szyderstwem odbieży.
L. S.

Tam mi zastapią miejsce towarzyszy, Zastapią miejsce przyjaciół i braci Wilk bury, tygrys wysmukłej postaci I grzywiasta hyjena, co za mordem dyszy. Przed nimi możesz tajnie swe otwierać, Oni tak milcza, jak trupi w mogile, Przed nimi nie trza ze słabości chwili Wzgardę i łzy milczące cały wiek pożerać.

Zarówno A. M., jak i L. S. potrzebowali co najmniej sześciu wersów, by w sposób petycki oddać w języku polskim sens odpowiadający czterem hemistychom tekstu arabskiego. Poza znacznie bardziej ubarwionym opisem zwracają uwagę pewne niezgodności dotyczące charakterystyki występujących w tekście dzikich zwierzat. Ar. "'amallasun” odnosi sie do cech witalnych (mocny i szybki), a nie do ubarwienia sierści („płowy” u A. M. i „bury” u L. S.), ar. „arqaț” jest epitetem o znaczeniu 'plamisty', który przez Aš-Šanfarę użyty został metonimicznie zamiast dosłownego „lampart” (a nie „tygrys” jak u Spitznagla), ar. „"arfă $\tilde{a}^{3} u$ [długogrzywa]” to pierwotnie substantywizowany przymiotnik, który z czasem zaczął oznaczać gatunek takiej właśnie hieny - w tłumaczeniu A. M. pominięty.
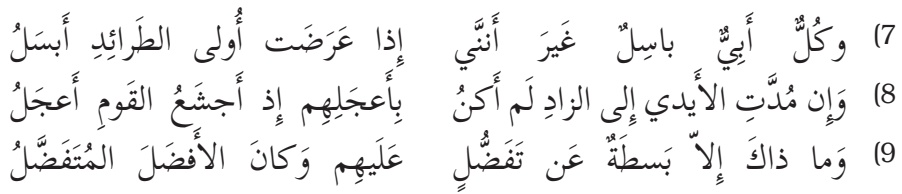

7) wa-kullun abiyyun bāsilun ġayra anna-n̄̄

id̄a $\bar{a}^{c}$ aradat ūlā țtară ${ }^{\top} i d i$ absalu

8) wa-in muddati l-aydī ilā z-zādi lam akun

bi-a $a^{c} \breve{g} a l i-h i m$ id a ăs̆a $a^{c} u$ l-qawmi a $a^{c} \breve{g} a l u$

9) wa-mā dāka illā basțatun ' an tafaḍulin

calay-him wa-kāna l-afḍala l-mutafaḍdalu 
Tłum. fil.:

7) A każdy z nich dumny, waleczny - ale ja, gdy pierwszy pościg się wyłoni, waleczniejszy [jestem od nich].

8) A jeśli ręce po jadło się wyciągną, nie będę szybszy od nich, gdyż [tylko] najbardziej łapczywemu spieszno.

9) I nie jest to [z mojej strony] nic innego, jak tylko obfitość łaskawości dla nich, bo kto łaskawszy, łaskawością jest obdarzany.

A. M.

U nich na krzywdę zemsta, na gwałt moc gwałtowna. Waleczni, ale w męstwie żaden mi nie zrówna.

Nieprzyjaciołom pierwszy ja skaczę do oczu,

A gdy przyjdzie łup dzielić, stoję na uboczu.

W dziale łupów łakomstwo chyżością zwycięża,

Ja czynię obyczajem dostatniego męża;

Nikt wielkością umysłu nie zdoła mi sprostać,

A kto czuje swą wyższość, godzien przy niej zostać.

Przekład L. S. został mocno skrócony - pomija zupełnie wątek, w którym Aš-Šanfarā chełpi się swoją zacnością i wywyższa się ponad innych. Interpretacja A. M. - pomimo dołączonego motywu krzywdy i zemsty oraz zastąpienia łaskawości wielkością umysłu i wyższością - dobrze oddaje treść tekstu arabskiego.
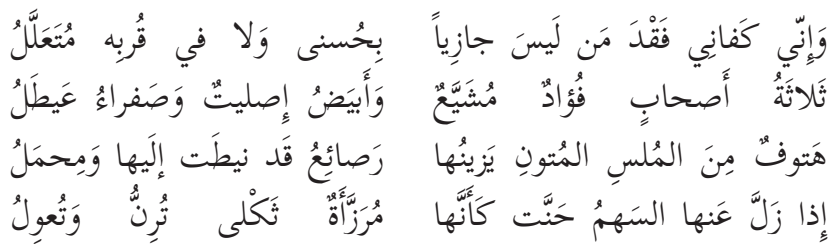

10) wa-in-nī kafā-nī faqda man laysa $a^{23}$ ğāziyan

bi-husnā wa-lā fi qurbi-hi mutacallalu

11) talātatu așhābin fư ādun mušayya ${ }^{c}$ un wa-abyaḍu iṣlitun wa-șafră $\bar{c}^{\top}$ ayțalu

12) hatūfun mina l-mulsi l-mutūni yazinnu-hā rașă $\bar{i}^{\top}$ u qad nütat ilay-hā wa-mihmalu

13) id murazza atun taklā turinnu wa-tuci wilu

Tłum. fil.: pożytku,

10) A powetowali mi brak tego, który nie nagradza dobrem, i [tego], z którego bliskości nie ma

11) trzej druhowie: waleczne serce, biała, obnażona szabla i długi, żółty łuk,

12) dźwięczny, z twardego i gładkiego kija, który zdobią przywieszone doń paciorki i pas.

13) Gdy strzała się z niego wyśliźnie, zajęczy jak utrapiona stratą dziecka [matka], która kwili i lamentuje.

A. M.

Porzucam was i tęsknić nie będę za wami, Których nie przyciągnąłem dobrodziejstw więzami
L. S.

Dobrze mi jednak wśród tych nowych braci, Którym dobroć ni groźba serca nie ugłaszcze

23 W chrestomatii de Sa cy’ego (op. cit. 〈1806〉, t. 1, s. 312) błędnie: سَّنَ „lasta”. Por. Dīwān

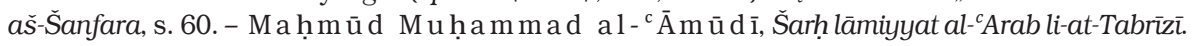
„Mağallat Machad al-Mahț̣̄tạ̄t al-'Arabiyya” 1997, nr 41, t. 1, s. 149. 
I do których nie lgnęło nigdy serce moje. Dosyć mam towarzystwa, gdy zostało troje: Serce waleczne, szabla, z której ognie bijac, I łuk żółty wielbłądzią krzywiący się szyją, Przy którym pas bogaty, suta frędzla pływa, Majdan gładko ciosany i tęga cięciwa, Co tak żałośnie jęczy, gdy z niej grot wyleci, Jako matka wydarte ścigająca dzieci.
I którym za krwią dyszą osoczone paszcze; Tak dobrze - póki Szanfary nie straci Duszy z kamienia, serca ze stali, Szabli, co błyska mignieniem się fali, I łuku mego od srebra i złota, Co kiedy strzałę wyrzuci z cięciwy, W puste powietrze rzuca dźwięk płaczliwy, Tak jako jęczy nieszczęsna sierota.

We fragmencie tym użyte zostały metonimicznie desygnaty dwu barw. Pierwszy wyraz, „abyad” (dosł. „biały” - w domyśle: „błyszczaccy”), symbolizuje szablę lub miecz - o tym, że tak powinien być odczytany, upewnia następujący po nim przymiotnik „ișlì”' (dosł. „dobyty z pochwy”, „obnażony”, „, nagi”). Drugi to „șafra „żółta”) oznaczający łuk ${ }^{24}$, na co wskazuje rozwinięcie w kolejnym wersie. W przekładzie oba określenia metonimiczne ze względu na nieprzetłumaczalność zostały potraktowane jak zwykłe przymiotniki i dla klarowności uzupełnione lub zastapione rzeczownikami (,szabla”, „łuk”). W wersji Mickiewiczowskiej zwraca uwagę fraza „wielblądzią krzywiący się szyją, opisująca łuk. Odpowiada ona określeniu „ "ayțalu” w tekście arabskim, będącemu synonimem „țawïl, czyli „długi” (tu w odniesieniu do łuku), które już według najstarszych arabskich dykcjonarzy miało też węższe znaczenie, tj. 'o długiej szyi' ${ }^{25}$. Jednak w przekładzie francuskim brak dokładnego odpowiednika tego określenia - w obu wydaniach de Sacy ograniczył się do przymiotnika „długi” (fr. „long”). W węższym znaczeniu pojawia się ono dopiero w uwagach do tłumaczenia kasydy w wersji z 1826 roku $^{26}$. Czyżby więc, wbrew opinii wyrażanej m.in. przez Romana Pilata ${ }^{27}$, Mickiewicz miał jednak wgląd do drugiego wydania Chrestomathie arabe? A może tak wyjątkowo udane w tym przypadku tłumaczenie to po prostu efekt konsultacji z orientalistą Sękowskim?

We fragmencie tym A. M. wiernie, $z$ drobnymi odstępstwami, oddaje istotę tekstu oryginalnego. W interpretacji L. S. widoczna jest większa dowolność: zbyt rozbudowana i niezgodna $z$ sensem wersji arabskiej parafraza wersu 10 zamiast o walecznym sercu mówi o „Duszy z kamienia” i „sercu ze stali”, opis łuku bardzo zredukowany i znacznie odbiegajacy od wersji arabskiej.

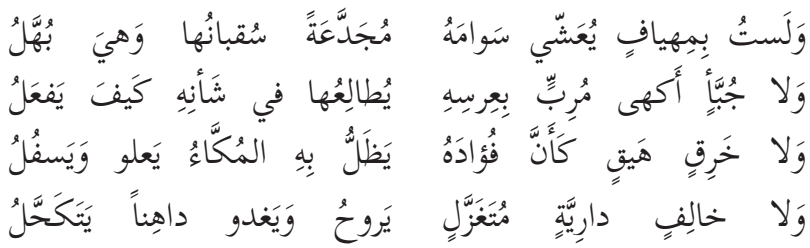

Nawiązuje to do barwy drewna, $\mathrm{z}$ jakiego wytwarzano łuki (pozyskiwanego najprawdopodobniej z krzewu Grewia populifolia (ar. „an-nab ${ }^{\text {") }}$ z rodziny lipowatych (Tiliaceae).

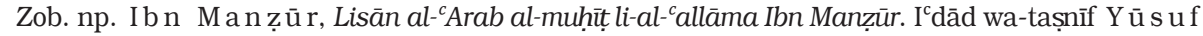
H a y y āț. Bayrūt, b.r.

Zob. de S a cy, op. cit. (1826), t. 2, s. 356: „Quant à عيْطَ , il se dit proprement d'un chameau ou d'un cheval qui a le cou long [Jeśli idzie o عيْطَ), to odnosi się zwłaszcza do wielbłąda lub konia o długiej szyil".

R. Pilat, Tekst francuski wiersza „Szanfary”. „Pamiętnik Towarzystwa Literackiego imienia Adama Mickiewicza" 1889, s. 258-259. Zob. też aneks do niniejszego artykułu. 


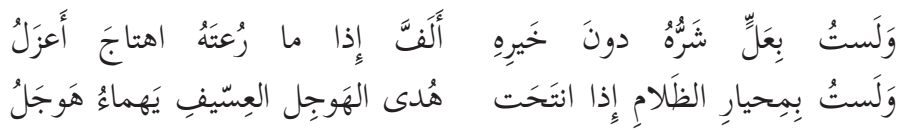

14) wa-lastu bi-mihyāfin yucaššì sawāma-hu muğaddacatan suqbānu-hā wa-hya buhhalu

15) wa-lā ğubba in akhā muribbin bi- ${ }^{c}$ irsi-hi yuțālicu-hā fi šs $a^{\supset}$ ni-hi kayfa yaf ${ }^{c} a l u$

16) wa-lā hariqin hayqin ka anna fu $u^{0} d a-h u$ yazallu bi-hi l-mukkā̄u ya $a^{c}$ lu wa-yasfulu

17) wa-lā hāalifin dāriyyatin mutaġazzalin yarūḥu wa-yaǵdū dāhinan yatakaḥ̣alu

18) wa-lastu bi-c ${ }^{c}$ allin šarru-hu dūna hayri-hi alaffa id̄ā mā ructa-hu htāğa a $a^{c} z a l u$

19) wa-lastu bi-mihyāri z-zalami idāa ntahat hudā l-hawğili l-cissīifi yahmā $\bar{a}^{3} u$ hawğalu

Tłum. fil.:

14) Nie jestem tym, co, na pragnienie nieodporny, na daleki wypas aż do zmroku wychodzi ze stadem, którego przychówek pozostaje niedożywiony, choć wymiona matek nie zostały podwiązane ${ }^{28}$, robić,

15) ani ślamazarnym tchórzem adorującym swą kobietę, radzącym się jej we wszystkim, co ma

16) ani przerażonym strusiem, którego serce niczym skowronek raz się wznosi, raz opada,

17) ani rozkapryszonym amantem, co po domach się umizga i od rana do wieczora [wonnymi] olejkami i czernidłem się zdobi.

18) Nie jestem zasuszonym starcem, z którego pożytku nie ma, a gdy go nastraszysz, kuli się i truchleje bezbronny.

19) Nie jestem bezradny w mroku, niczym błądzący na pustyni głupiec bez drogowskazu.

\section{A. M.}

Jam nie sługa pragnienia, co się w noc zaczaja I odstraszywszy źrzebce sam klacze wydaja. Jam nie tchórz ni za dziewic ogonem włocęga, Co w każdej drobnej sprawie rady ich zasięga. Nie strusie serce moje; choć strach zakołata, Nierównym pędem w piersiach jak wróbel nie lata. Kto mię widział od rana do nocy śród gachów, Brew malować, włos trefić w kapieli zapachów? Czy mię kiedy noc zbłąka, choć piaszczysta fala Tumanami okręci i żwirem zawala?

\section{S.}

Nie jestem ja $\mathrm{z}$ tych i słabych, i marnych, Co osłabieni w południe dni skwarnych, Chcąc rozognione gardła napoić, Odganiając cielęta od matek swych łona, Cisną wielbłądzie wyschłe wymiona,

By $z$ nich ostatnią kroplę wydoić.

Nie jestem $z$ tych, co kobiet otoczeni kołem, Z nimi się żywią, z nimi mieszkają pospołem A serce, które w ich piersi się więzi, Tak jest pierzchliwe, jak serduszko czyża, Tak się wznosi, tak się zniża, Jak kołysany ptaszek na gałęzi, Którzy szczęście znajdują w domowym więzieniu, W kunsztownych woniach i lic kraszeniu; Wad żadną cnotą okupić niezdolni, Zawsze drżą trwogom dziecinnym powolni. Trwoży ich głos surowy, zapalone oczy, I noc, kiedy ich w gołej pustyni zaskoczy.

Treść wersu 14 sprawia wrażenie niedopowiedzenia, jakby wybór interpretacji pozostawił poeta celowo wyobraźni odbiorcy. Tymczasem przekłady zarówno A. M., s. 151. 
jak i L. S. brzmia jednoznacznie i mają analogiczna wymowę, przy czym L. S. poświęcił tym dwu hemistychom aż sześć linijek. Nie wiadomo natomiast, dlaczego także obaj zignorowali zupełnie wers 18 kasydy, który przecież w tłumaczeniu francuskim nie został pominięty.

Wersy 14-19 poematu Aš-Šanfary zbudowane są na anaforze (,wa-lastu” oraz „wa-lä”), jednak w przekładach figura ta nie znalazła odzwierciedlenia, chyba żeby za jej ekwiwalent uznać rozpoczęcie oddalonych od siebie wersów zwrotem „Jam nie” (A. M.) lub „Nie jestem” (L. S.). W tekście A. M. pewną rekompensatę stanowią dwa występujące bezpośrednio po sobie pytania retoryczne pod koniec tego fragmentu.
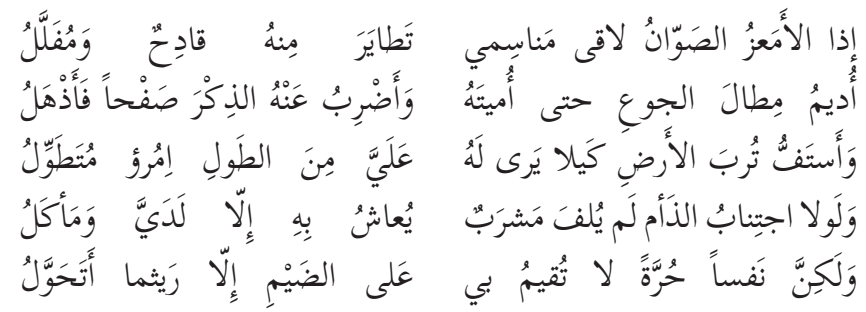

20) î̉ā l-amcazu ș-șawwānu lāqā manāsim-ī tațāyara min-hu qādihun wa-mufallalu

21) udìmu mitāla l-ğù $\bar{u}^{c}$ ḥattā umìta-hu wa-adribu ${ }^{c} a n-h u \underline{d}$-dikra șafhan fa-adhalu

22) wa-astaffu turba l-arḍi kaylā yarā la-hu calay-ya mina ț-țawli mru'un mutatawwilu

23) wa-lawlā ğtinābu $\underline{d}-\underline{d} a^{3}$ mi lam yulfa mašrabun yu'āšu bi-hi illā laday-ya wa-maºalu

24) wa-lakinna nafsan hurratan lā tuqūmu $b-\bar{\imath}$ calā ḍ-ḍaymi illā rayțamā atahawwalu

Tłum. fil.:

20) Gdy mi żwir pod kopyta podejdzie, iskry się z niego rozprysną i drobne kamyki,

21) głód długotrwały znoszę, aż go uśmiercę, a pamięc o nim na bok odsunę i zapomnę.

22) [Prędzej] proch ziemi łykał będę, nim mnie łaskawca [jakiś] łaską swą obdarzy.

23) Gdyby nie to, że ujmy się wystrzegam, miałbym ja picia i jedzenia dostatek,

24) ale duch niesforny [dosł. „gorzki”] nie zwiedzie mnie ku krzywdzie, póki od niej stronię.

A. M.

Lecę na mej wielblądce, wrą u nóg ukropy, Krzemienie iskry sypiąc pryskają spod stopy. O głodzie, choć najdłuższym, w wielkomyślnej dumie

Nigdy wspomnieć nie raczę, i tak go zatłumię. Karmię się prochem ziemi, a głód nadaremnie Pasując się wyznaje, że słabszy ode mnie. Gdybym został w obozie, gdzież więcej napitków, Więcej jadła niż u mnie do potrzeb i zbytków? Ale mam duszę gorzką, co się $z$ hańbą kłóci, I jeśli was nie rzucę, dusza mię porzuci.
L. S.

Ja gołą noga przebiegam drogi, Krzemień pustyni pod nogą mą skrzypie, Pęka się pod nią i w iskry się sypie. Umiem cierpliwie znosić głód srogi I myśli moje od niego oddalić, Piasek pożeram, aby głód nie mniemał, Że jaką wyższość nade mną otrzymał.

Żeby tylą krzywdami świat mnie nie obarczył, Żem w tych pustyniach szukał pokoju, Żaden by dom na pewno tyle nie dostarczył Ile mój dom - bogactwa, jadła i napoju. Lecz wtenczas duch mój, duch mój wyrwałby się z łona,

Z odrazą martwe ciało by zostawił,

Gdybym choć chwilkę jeszcze, choć chwilkę zabawił Wśród znienawidzonego śmiertelników grona 
Wyraz „kopyta” (dosł. „moje kopyta”) w wersie 20 użyty został przenośnie dla podkreślenia wyjątkowej chyżośsi ${ }^{29}$. Aš-Šanfarā bowiem, według narosłej wokół niego legendy, cieszył się sławą niezrównanego biegacza, któremu konie prędkością nie mogły dorównać. Przekład L. S. jest więc zdecydowanie wierniejszy. Natomiast wprowadzenie przez A. M. „wielblądki” po raz kolejny zaskakuje zbieżnością z tłumaczeniem de Sacy'ego z roku 1826: „Quand les pieds de ma monture rencontrent une terre dure et semée de cailloux, ils en tirent des étincelles et les font voler en pièces [Gdy nogi mojego wierzchowca napotykają twardą ziemię usianą kamieniami, rzucają iskrami, rozsypując je na drobne kawałki]" 30 .

Zastanawiające jest, że wers 22 obaj poeci potraktowali jako zwykłe rozwinięcie motywu mocowania się $z$ głodem $z$ wersu poprzedniego, posługując się ponadto $\mathrm{w}$ bardzo podobny sposób antropomorfizacją. Interpretacja ta pokrywa się $\mathrm{z}$ tłumaczeniem francuskim z pierwszego wydania Chrestomathie arabe ${ }^{31}$, natomiast odbiega zarówno od oryginału, jak i od dokładnego w tym wypadku przekładu de Sacy'ego z 1826 roku $^{32}$.
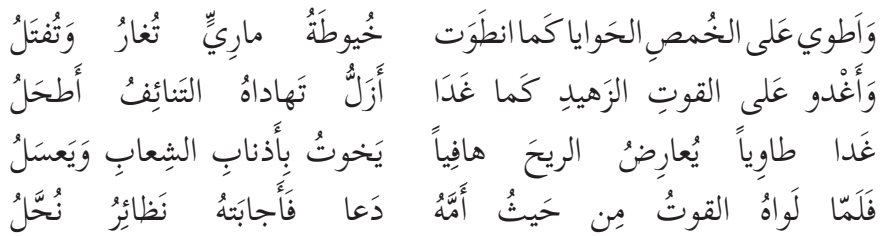

25) wa-ațwī calā l-humși l-hawāyā kamā nțawat

huyūtatu māriyyin tugiāru wa-tuftalu

26) wa-ag்dū calā l-qūti z-zahīdi kamā ġadā azallu tahādā-hu t-tanā̃ifu athalu

27) ġadā tāwiyan yu āridu r-rüha hāfiyan yahūtu bi-adnābi š-šicābi wa-ya ${ }^{c}$ salu

28) fa-lammā lawā-hu l-qūtu min hayț̣u amma-hu

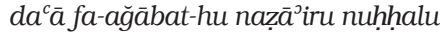

Tłum. fil.:

25) Przeciw głodowi wnętrzności me skręcam, jak sznury przez powroźnika zaciskane i splatane.

26) Za strawą nędzną świtem wychodzę jak wychudły, rdzawy wilk, co po pustyni [w poszukiwaniu żeru] się tłucze,

27) który, o głodzie rankiem wyruszywszy, do wiatru się ustawia, słaniając się, przemykając ścieżkami wśród wzgórz,

28) a gdy żeru nie znalazł tam, gdzie zmierzał, zawył i odpowiedziały mu podobne mu chudzielce.

A. M.

Teraz pragnienie skręca wnętrzności w mym łonie, Jak nić różnie targaną na prządki wrzecionie.
L. S.

Ze świtem dążę w pustynię i skały, Tak jak wilk dziki, tak jak wilk zgłodniały, Co lasów głuche odwiedza zacisze;

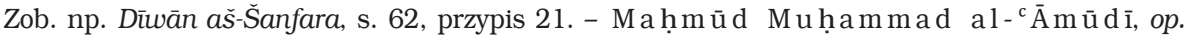
cit., s. 153.

De S a cy, op. cit. (1826), t. 2, s. 339. Natomiast w wydaniu z 1806 r. jest: „Quand mes pieds rencontrent une terre dure et semée de cailloux, ils en tirent des étincelles et les font voler en pièces [Gdy moje nogi napotykają twardą ziemię usianą kamieniami, rzucają iskrami, rozsypując je na drobne kawałki]".

De S a cy, op. cit. (1806), t. 3, s. 4.

De S a cy, op. cit. (1826), t. 2, s. 339. 
$Z$ rana wybiegam na czczo podobny wilkowi, Co wygłodniały hasa i wiatr paszczą łowi, I z pustyni w pustynie, w wąwozów rękawy, Przeciska się włocęga czatujący strawy;

A gdy na długich czatach darmo się utrudzi, Wyje, wtórują wyciem towarzysze chudzi.
$Z$ poranka głód mu dopieka surowy, On się zapuszcza w dzikie parowy I tam za krwią biesiadną dysze... Leczy gdy mu nazbyt wnętrze głód wyjada, Strasznie zawyje wśród pustyni ciszy, Wtenczas z gór okolicznych echem odpowiada Głos wygłodniałych jego towarzyszy.

Tłumaczenie A. M. zgadza się z tekstem arabskim pod względem tak liczby wersów, jak i zawartych w nich poetyckich obrazów oraz ich uszeregowania w przestrzeni wierszowej. Zachowane też zostało porównanie związane ze skrętem wnętrzności wywołanym głodem (w. 25), choć A. M. nieco je przetworzył, zastępując sznur nicią wrzeciona. L. S. porównanie to zupełnie pominąl, rozbudowując w zamian za to zawarty w wersach 26 i 27 motyw wygłodniałego wilka poszukującego żeru oraz ubarwiając opis takimi frazami jak „lasów głuche odwiedza zacisze” czy „za krwią biesiadną dysze".

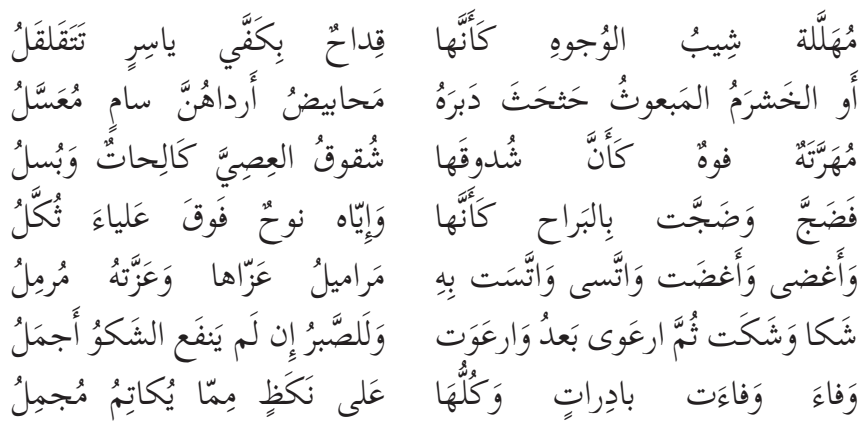

29) muhallalatun šǐbu l-wuğūhi ka anna-hā qidāhun bi-kaffay yāsirin tataqalqalu

30) awi l-hašramu l-mab üüu hathața dabra-hu mahābīịu ardā-hunna sāmin mu $u^{c}$ assalu

31) muharratatun fü-hu ka anna šudūqa-ha šuqūqu l-cișiyyi kālihạtun wa-bussalu

32) fa-dağğa wa-ḍağğat bi-l-barāhi ka anna-hā wa-iyyā-hu nūhun fawqa ${ }^{c}$ alyă $\bar{a}^{\top} a$ tokkalu

33) wa-aǵd̆a wa-ag்ḍat wa-ttasā wa-ttasat bi-hi marāmīlu ${ }^{c} a z z \bar{a}-h \bar{a}$ wa- ${ }^{c}$ azzat-hu murmilu

34) šakā wa-šakat tumma $r^{c} a w \bar{a} b a^{c} d u$ wa-r ${ }^{c} a w a t$ wa-la-șsșabru in lam yanfa ${ }^{c} i$ š-šakwu ağmalu

35) $w a-f \bar{a}^{\supset} a$ wa-fă $\bar{a}^{\supset}$ at bādirātin wa-kullu-hā 'alā nakażin mimmā yukātimu muğmilu

Tłum. fil.:

29) Wynędzniałe, o siwych pyskach, dygoczace jak strzały w dłoniach gracza ${ }^{33}$

30) albo rozwścieczona królowa pszczól, której rój rozjuszyły patyki wetknięte przez wybierającego miód,

33 Chodzi o zakazaną później przez islam grę hazardową o nazwie „maysir”, w której stawką było najczęściej mięso wielbłąda (.,ğazūr") poćwiartowanego w tym celu na 10 części, za przybory zaś służyły specjalnie oznakowane strzały pozbawione grotów i piór („qidḥ”). Grze tej poświęcił jedno ze swoich dzieł żyjący w IX w. I b n $\mathrm{Q}$ u ta y b a (Al-Maysir wa-al-qidāḥ. Nasaḩa-hu wa-șaḥḥaḥahu wa- ${ }^{c}$ allaqa ${ }^{c}$ alay-hi wa-waḍaca fahārisa-hu Mu hị b ad - Dīn al- Huațīb. Al-gāhira 1924). 
31) z rozdziawionymi paszczami i nasrożonymi pyskami podobnymi do rozszczepionych kijów.

32) Zawył na pustkowiu i one zawyły niczym osierocone płaczki na wzgórzu,

33) ucichł i one ucichły, pocieszył i one go pocieszyły, głodującym okazał współczucie i one mu współczucie okazały,

34) poskarżył się i one się poskarżyły, aż wreszcie przestał i one przestały, cierpliwość wszak, jeśli narzekanie na nic się zdaje, piękniejsza jest,

35) zawrócił i one szybko zawróciły, a każdy z nich, dotkliwy głód skrywając, pełen cierpliwości.

\section{A. M.}

Jako z łonem niepełnym wschodni księżyc cieńki, Tak zapadłe ich boki, wychudłe paszczęi. Zęby dzwonia jak strzały we wróżka prawicy Albo jak roje pszczelne, gdy wkoło rodzicy Szumiąca polatują na pagórek rzeszą, Gdzie drabinki bartnika gronami obwieszą. Paszcza ich wychudzona, ponura i gniewna, Gardziel rozdarta na kształt rozkłutego drewna.

Zawył: i oni wyja biegąc na pagórki Jak płaczące farysa małżonki lub córki; Umilkną: oni milczą. Wycie mu ulżyło, I dla nich słyszeć równie wyjącego miło. Zda się, że spólność głodu wnętrzności uciszy; Znowu skarży się, znowu skarżących się słyszy, Umilkł w końcu, umilkła wrzaskliwa gromada. Lepiej w milczeniu cierpieć, gdy wrzask nic nie nada. -
L. S.

Wychudłe, blade i z źrenicą krwawą, Ale sa głodem miotani tak żwawo, Jak strzały z dzielnej łucznika dłoni, Lub jak rój pszczeli na powietrznej błoni; Jeden zawyje i zawyją wszyscy, Tak jak na wzgórzu smutne matki płaczą, Gdy ległych synów w dolinie obaczą Wyją okropnie, a skonania bliscy, Każdy z nich duszę taką myślą żywi, Że sa i drudzy jak on nieszczęśliwi; I znów zawyją, i znowu przestaną. Bo tam, gdzie rozpacz na próżno pada, Milczeć i cierpieć najlepsza jest rada. I potem wszyscy razem powstana I chociaż wspólnym goreją cierpieniem, Każden z nich śmiałym nadrabia wejrzeniem.

Przekład de Sacy'ego, zgodnie z oryginałem arabskim, nie pozostawia wątpliwości, że strzały, o których mowa w wersie 29 , służą do rzucania losów. A. M., zapewne dla spotęgowania atmosfery grozy i tajemniczości, włożył je w rękę „wróżka”34, L. S. zaś w dłoń łucznika. Ostatecznie jednak sens całego porównania zawartego $w$ tekście arabskim lepiej oddaje wersja L. S. - wilki całe dygoczą $z$ głodu, a nie tylko ich „zęby dzwonią". Z kolei tłumaczenie następnych dwóch wersów jest wierniejsze u Mickiewicza - nie zabrakło w nim królowej pszczół ani przyczyny rozdrażnienia roju (tu: „drabinki bartnika”), ani też porównania wilczych pysków do „rozkłutego drewna”.

Tutaj, mniej więcej w połowie kasydy Aš-Šanfary, kończy się przekład L. S. Oddanie treści zawartej w tym fragmencie zajęło u A. M. 76 wersów, jak zauważył Bobolewski ${ }^{35}$, a więc o 16 mniej niż u L. S. Dalsza analiza będzie dotyczyć już tylko tekstu A. M.
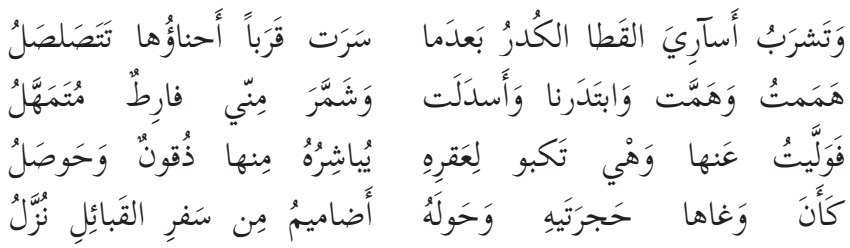

W przypisie Mickiewicz (Wybór poezyj, s. 177) dodał wyjaśnienie: „Dawni Arabowie poganie mieli w świątyni mekkańskiej strzały wyroczne zalam, z których rozmaitego mieszania wróżono o przyszłości". 

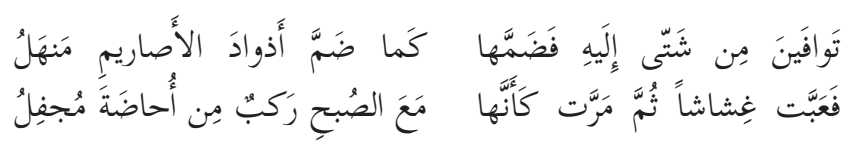

36) wa-tašrabu asāriya l-qațā l-kudru bac damā sarat qaraban ahna $\bar{a}^{\jmath} u$-hà tatașalșalu

37) hamamtu wa-hammat wa-btadarnā wa-asdalat wa-šammara min-nī färitun mutamahhalu

38) fa-wallaytu can-hā wa-hya takbū li- ${ }^{c} a q r i-h i$ yubāširu-hu min-hā duqūnun wa-hawșalu

39) ka anna wag̀ā-hā hağratay-hi wa-hawla-hu aḍāmīmu min safri l-qabā’ili nuzzalu

40) tawāfayna min šattā ilay-hi fa-ḍamma-hā kamā ḍamma ad wāda l-aṣārūmi manhalu

41) $\mathrm{fa}^{\mathrm{c}}{ }^{\mathrm{a}} \mathrm{abbat}$ gišāšan tumma marrat $k a^{\mathrm{a}}$ anna-hā $m a^{c} a$ ș-șubhi rakbun min uhāḍata muğfilu

Tłum. fil.:

36) Pokryte kurzem stepówki ${ }^{36}$ spijają resztki wody po tym, jak przez noc [całą z zaschniętymi trzewiami zdążały do wodopoju.

37) Zawziąłem się i one się zawzięły, ruszyliśmy na wyścigi i skrzydła im opadły, a ja z lekkością, niczym przewodnik, wyrwałem się pędem.

38) Zostawiłem je w tyle padające na skraju studni, z dziobami i brzuchami przywartymi do jej brzegów,

39) a szczebiot ich wszędzie wokół niej podobny do gromady plemiennej, co karawaną na postój się zatrzymała.

40) Zleciały się do niej zewsząd i przyjęła je tak, jak zdrój wody stadka wielbłądów przyjmuje.

41) Ugasiły prędko pragnienie, a potem odleciały, jak jeźdźcy [plemienia] Uhạạạa rankiem w pośpiechu wyruszający.

\section{A. M.}

Jeśli do studni jadę, lecacy pułk strusi Daremnie grzmi skrzydłami, męty spijać musi. Nie zgonił mej wielblądki bystry ich wódz stada; Ja dojeżdżam, spragniona zostaje gromada. Jużem odjechał. - Ptastwo runęło na męty, Wola ich rozciagnione, dziob ku studni zgięty Jest posłem dobrych wieści; wre ciżba hałasem Jak obóz karawany siedzącej popasem.

Znowu śmignęły w górę, znowu w studnie wpadły, Ścisnęły się na koniec i zręby obsiadły, I ryczałtem wypiwszy, rozwinęly loty, Jak runące $z$ oazy Beduinów roty.

Mickiewiczowski Szanfary konsekwentnie nie schodzi z „wielblądki”. Na dodatek ściga się ze strusiami, a nie, jak w tekście arabskim, ze stepówkami, choć w przypisie do wiersza A. M. zamieszcza następujące objaśnienie:

Ar. „qațā” - stepówka (Pterocles), niewielki ptak występujący na obszarach stepowych i półpustynnych oraz na płaskowyżach, na których roślinność jest nieliczna. W poszukiwaniu wody ptaki te mogą przebyć odległość nawet do $80 \mathrm{~km}$. Niektóre gatunki przynoszą wodę młodym w żołądku i w piórach na brzuchu. De S a cy zostawił to słowo nie przetłumaczone, trochę je tylko „sfrancużając” - „les kata” (op. cit. 〈1806〉, t. 3, s. 6) oraz „les katas” (op. cit. 〈1826〉, t. 2, s. 341). 
W oryginale jest tu mowa nie o strusiach, ale o ptastwie zwanym Katho, wielkości kruka. W poezji arabskiej często znajdujemy wzmiankę o tym ptastwie przelatującym stadami pustynie Arabii. Farys powinien znać położenie źródeł w pustyni, ażeby wiedział, gdzie ma popasać ${ }^{37}$.

Przy okazji odnosi się wrażenie, że wiedza naszego wieszcza na temat strusi musiała być nader ogólnikowa, skoro w dalszych linijkach przekładu każe on owym nielotom „smigać w górę” i „,rozwijać loty”. Chyba że, mówiąc: „Ptastwo runęło na męty”, poeta miał na myśli jakieś inne jeszcze ptaki, które w drugiej kolejności obsiadły studnię - co jednak byłoby znaczącym odejściem od sensu pierwotnego.

Zwraca też uwagę nieco manierycznie brzmiąca fraza „dziób ku studni zgięty / Jest posłem dobrych wieści”.

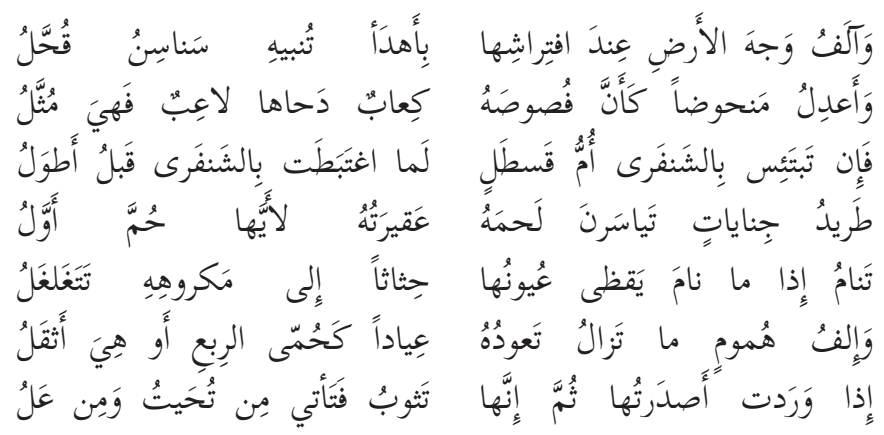

42) wa-ālafu wağha l-arḍi cinda ftirāši-hā

bi-ahda a tunbi-hi sanāsinu quhḥalu

43) wa-a dilu manhūụan ka anna fușūṣa-hu kicābun dahāa-hā lā ${ }^{c}$ ibun fa-hya muttalu

44) fa-in tabta ${ }^{3}$ is bi-š-Šanfarā Ummu Qasțalin la-mā ġtabațat bi-š-Šanfarā qablu ațwala

45) țarīdu ğināyātin tayāsarna laḥma-hu ${ }^{c}$ aquiratu-hu li-ayyi-hā ḥumma awwalu

46) tanāmu id̄ā nāma yaqzạ̄ cuyūnu-hā hịtātan ilā makrūhi-hi tataġalġalu

47) wa-ilfu humūmin mā tazālu ta $a^{c} \bar{d} d u-h u$ ${ }^{c}$ iyādan ka-ḥummā r-rib ${ }^{c} i$ aw hiya ațqalu

48) id $\underline{\text { a }}$ waradat așdartu-hā tumma inna-hā tațūbu fa-ta ${ }^{\mathrm{t}} \overline{\mathrm{t}}$ min tuhaytu wa-min ${ }^{c}$ alu

Tłum. fil.:

42) Przywykłem kłaść się na ziemi wsparty na boku o wystających suchych kościach,

43) z chudą ręką pod głową, której sterczące kostki [stawów] podobne są do kości przez gracza rzucanych.

44) Jeśli wojna [dosł. „matka kurzu”] za Szanfarym [teraz] tęskni, to przecież przedtem długo się nim cieszyła. niczką.

45) Wygnaniec za nieprawości, które o jego ciało los rzuciły, jego dusza każdej z nich jest zakład-

46) Gdy on śpi, one śpią z otwartymi oczami, spieszno im osiagnąc to, co mu nienawistne.

47) Kompan kłopotów powracających doń ciagle jak czterodniowa gorączka albo nawet cięższych,

48) gdy się zjawiają, odpędzam je, a one ciągle wracają, przychodząc to $z$ dołu, to $z$ góry. 
A. M.

Ziemia twarda mnie drużka, nieraz do jej łona

Tuliłem kark mój suchy i chude ramiona,

Których stawy sterczące tak policzyć snadno

Jak kostki, co z rąk gracza na ławę wypadną.

Jeżeli wojna tęskni za Szanfarym sługá,

Toć Szanfary jej służył i wiernie, i długo.

Dziś nieszczęście w mą duszę jak w piłkę zagrało,

Boleści podzieliły losem moje ciało ${ }^{38}$.

Każda bieda najpierwej na mój kark się wsuwa;

Kiedy zasypiam, bieda u głów moich czuwa

I wytrzeszczywszy oczy patrzy, skąd ugodzić.

Troski koleją febry zwykły do mnie chodzić,

Ale od febry gorzej nie daja pokoju,

Leca do mnie jak ptaki spragnione do zdroju;

Sto razy je odpędzisz, i setnymi chmury

Znowu uderzą $\mathrm{z}$ boku i z dołu, i z góry.

Ta część przekładu A. M. z dużą precyzją oddaje sens poszczególnych wersów tekstu oryginalnego. Pewien dysonans stanowi jedynie tłumaczenie wersu 45 , a ściślej: użyte przez A. M. porównanie ,jak w piłkę zagrało”, które zupełnie nie pasuje do arabskiej rzeczywistości okresu przedmuzułmańskiego, jako że gry w piłkę - na czymkolwiek by ona polegała - ówcześni Arabowie po prostu nie znali.
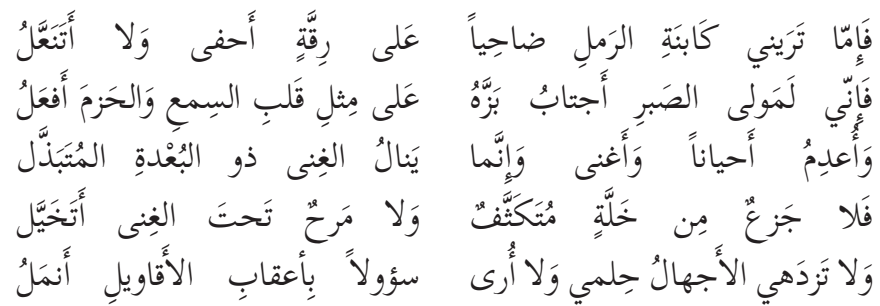

49) fa-immā taray-nī ka-bnati r-ramli ḍăhiyan 'alà riqqatin ahfā wa-là atana ${ }^{c c}$ alu

50) fa-in-nī la-mawlā ș-șabri ağtābu bazza-hu ${ }^{c}$ alā mitli qalbi s-simci wa-l-hazma af alu

51) wa-ucdimu ahyānan wa-ag̉nā wa-innamā yanālu l-gināa dū l-bucdati l-mutabaddalu

52) fa-lā ğazicun min hallatin mutakattafun wa-lā marihun taḥta l-g̈inā atahayyalu

53) wa-là tazdahì l-ağhālu hilm-ī wa-lā urā sa ūlan bi-a qābi l-aqāwīli anmalu

Tłum. fil.:

49) Jeśli [nawet] w twoich oczach [dosł. „postrzegasz mnie”] 39 jestem jak żmija [dosł. „córka piasku”] na skwar wystawiona, ubogi, bosy bez obuwia,

50) to [wiedz, że] ja wszak jestem uosobieniem [dosł. „panem”] cierpliwości, jej szatę noszę, [jestem] jak serce potomka wilka i hieny, postępuję nieugięcie.

Do tego wersu Mickiewicz (ibidem, s. 179) zamieścił następujący przypis: „Przenośnia wzięta ze zwyczaju Arabów, którzy zabiwszy wielbłąda, losem ciąna, jaka część komu się dostanie”.

W oryginale występuje tu forma czasownika w rodzaju żeńskim. 
51) Czasem jestem w niedostatku, a czasem w dostatku, lecz bogactwo zdobywa, kto nie szczędzi drogi.

52) Ubóstwem się nie zamartwiam i z nim się nie obnoszę, nie raduję się zbytkiem ani nie wywyższam,

53) mego opanowania głupcy nie wzruszą ani nie jestem uważany za wścibskiego, który plotki szerzy.

\section{A. M.}

Wiecie, jak w upał boso lecę przez pustynie,

Podobny córce piasku, błyszczacej gadzinie.

Choć miękko wychowany i z przodków bogaty,

Alem syn Cierpliwości, włożyłem jej szaty

Na pierś, w której hyjeny przemieszkiwa Śmiałość,

Za obuwie na nogi włożyłem Wytrwałość.

Na stepach bez namiotu, w skwary bez pokrycia,

Jam wesół i bogaty, bo nie szczędzę życia.

W dniach szczęścia dostatkami nie byłem odęty,

Głupie lenistwo dla mnie nie miało ponęty.

Czylim z nadstawnym uchem za plotkami latał?

Czylim na cudzą sławę potwarze wymiatał?

Tłumaczenie wersu 49 nie oddaje w pełni znaczenia tekstu wyjściowego. W wersie tym bowiem Aš-Šanfarā, ukazując mizerię swojego położenia, zwraca się za pomocą zdania warunkowego do swojej nie nazwanej z imienia wybranki serca (stąd forma rodzaju żeńskiego czasownika „taray”). W kolejnym wersie natomiast, będącym następnikiem okresu warunkowego, zapewnia o swoim harcie ducha i nieugiętości.

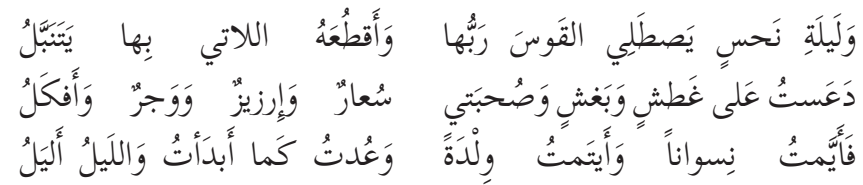

54) wa-laylati nahsin yaștali l-qawsa rabbu-hā wa-aqtuc ${ }^{c} a-h u$ l-lātì bi-hā yatanabbalu

55) da ${ }^{c} a s t u^{40}{ }^{c}$ alā ġațšin wa-baǵšin wa-șuhbat-ī sucārun wa-irzìzun wa-wağrun wa-afkalu

56) fa-ayymtu niswānan wa-aytamtu wildatan wa-c udtu kamā abda tu wa-l-laylu alyalu

Tłum. fil.:

54) Ileż to nocy bywało [tak] zimnych, że aż łuk swój spalić trzeba było [by się ogrzać] i strzały, którymi się razi.

55) Napadałem w noc ciemną i dżdżystą, a za towarzyszy miałem głód palący i dreszcze, przerażenie i ciarki.

56) Owdowiłem kobiety, osierociłem dzieci i tak, jak zacząłem, tak i wróciłem, gdy [była] noc ciemna.

A. M.

Pamiętacie noc klęski! tę noc niepogodną,

Noc tak straszliwie ciemną, tak okropnie chłodną,

Że Arab grzał się paląc własny łuk i groty.

Ja wybiegłem na boje śród mroku i słoty;

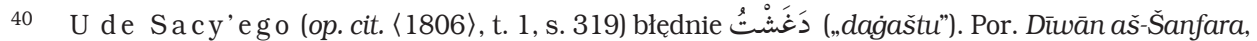
s. 70. - Maḥmūd Muḥammad al- ${ }^{c} \bar{A} m u \bar{d} \overline{1}$, op. cit., s. 168. 
Przewodniczką mi była błyskawic pożoga, Towarzyszami piorun, okropność i trwoga. Osierociłem dzieci, owdowiłem żony,

Wróciłem, jakem wyszedł, nocą otoczony.

Interpretacja ta została przez A. M. nieco ubarwiona (dotyczy to zwłaszcza opisu nocnej scenerii), jednak treści odpowiadające poszczególnym wersom arabskim nie różnią się, jak widać, zbyt mocno od wersji oryginalnej.
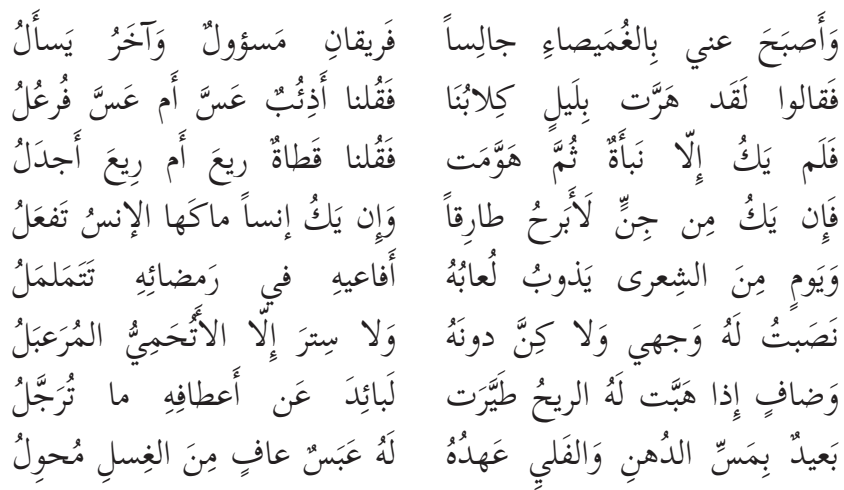

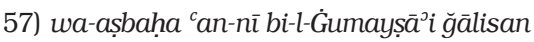
farīqāni mas ${ }^{3} \bar{l}$ un wa-āharu yas ${ }^{3} a l u$

58) fa-qālū laqad harrat bi-laylin kilābu-nā fa-qulnā a-di $i^{3}$ bun ${ }^{c}$ assa am ${ }^{c}$ assa fur ${ }^{c} u l u$

59) fa-lam yaku illā nab atun tumma hawwamat fa-qulnā qațātun $r^{-c} a$ am rī̃ a ağdalu

60) fa-in yaku min ğinnin la-abraḥu țāriqan wa-in yaku insan mā ka-hā l-insu taf ${ }^{c} a l u^{41}$

61) wa-yawmin mina š-ŠSic rā yadūbu lucābu-hu afā $\bar{c}^{c}-h i$ fì ramda $\bar{a}^{\supset} i-h i$ tatamalmalu

62) nașabtu la-hu wağh-ī wa-lā kinna dūna-hu wa-lā sitra illā l-athamiyyu l-muracbalu

63) wa-dāanin idāa habbat la-hu r-rịhu țayyarat

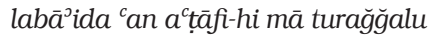

64) ba ${ }^{c} \bar{\imath} d u n^{42}$ bi-massi d-duhni wa-l-falyi ${ }^{c}$ ahdu-hu la-hu ${ }^{c}$ abasun ${ }^{c} a \overline{f i n}$ mina l-g̈isli muhwilu

Tłum. fil.:

57) Gdym w Al-Ġumayșāa przebywał, zaczęli o mnie jedni drugich rozpytywać.

58) Mówili: nasze psy w nocy warczały, więc pytaliśmy, czy to wilk krąży, czy hieny szczenię,

59) był tylko cichy odgłos, a potem [psy] posnęły, rzekliśmy więc: stepówka się spłoszyła albo sokół się spłoszył,

60) jeśli to był dżinn, to w rzeczy samej przepotężny, nocą przybywający; jeśli zaś człowiek, to wszak człowiek tak nie czyni.

61) Iluż to dniom, gdy Syriusz na niebie, żarem palącym tak, że aż żmije na rozpalonej ziemi [z bólu] się skręcały,

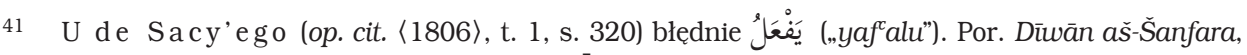

s. 71. - Maḥmūd Muḥammad al - '⿳亠口冋m ūdī, op. cit., s. 171.

42 U de Sa cy'e go (op. cit. 〈1806〉, t. 1, s. 321) błędnie („,ba بَعَdan”). Por. Dīwān aš-Šanfara,

s. 72. - Maḥmūd Muḥammad al- '⿳亠口冋mū dī, op. cit., s. 172. 
62) stawiałem czoła, nie mogąc się ukryć, a za odzienie miałem tylko poszarpany płaszcz

63) i gęste włosy zaniedbane, których strąkami podmuch wiatru targał,

64) dawno już nie natłuszczane i nie odwszawiane, brudem pokryte, od roku nie myte.

A. M.

Nazajutrz, gdym spokojnie w Gumaiza leżał,

Mówiono o mnie w stepach, którem w noc przebieżał.

Zeszła się nieprzyjacioł dwoista gromada,

Jedna $z$ nich zapytuje, druga odpowiada.

Słyszano, mówią, wczora nocne psów warczenie,

Zdało się, że wilk przebiegł lub hyjeny szczenię,

Albo ptak przebudzony skrzydłami gdzie musnął,

Bo pies zawarczał tylko i po chwili usnął.

Może to Diw przechodząc tyle szkody zrobił?

Może człowiek? - Nie, człowiek tylu by nie pobił.

Ja w dzień, gdy niebo wrzało ogniami letniemi,

Tak że zmije od skwaru skakały po ziemi,

W dziurawym płaszczu padłem na żwiry kipiące

I zdjąwszy turban głową wyzywałem słonce,

A włos mój brudu pełny, nie znający woni,

Kołtunami przylegał do niemytej skroni.

Poza dodanym motywem turbanu tłumaczenie, choć poetycko przetworzone, bardzo wiernie odzwierciedla treść oryginału. W przypadku wyrażenia „dwoista gromada", będącego odpowiednikiem ar. "farīqān [dwie grupy]", ociera się wręcz o dosłowność ${ }^{43}$.
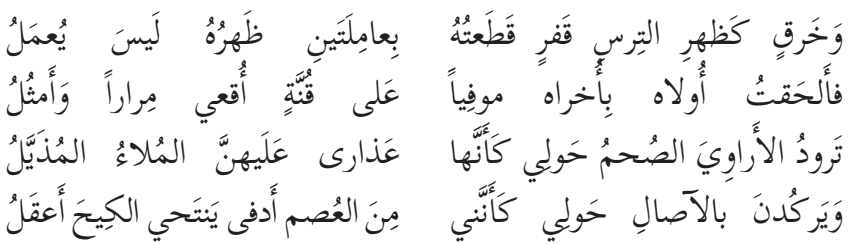

65) wa-harqin ka-zahri t-tirsi qafrin qatactu-hu bi- ${ }^{-} \bar{a}$ milatayni zahru-hu laysa yucmalu

66) fa-alhaqtu ūlā-hu bi-uhrā-hu mūfiyan

calā qunnatin uq ${ }^{c} \bar{\imath}$ mirāran wa-amtulu

67) tarūdu l-arāwiya ș-șuhmu ${ }^{44}$ hawl-ī ka-anna-hā

${ }^{c} a \underline{d} \bar{r} \bar{a}^{c}$ alay-hinna l-mulä u l-mudayyalu

68) wa-yarkudna bi-l-āṣăli hawl-ì ka-anna-nī

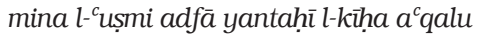

Tłum. fil.:

65) Ileż to jak grzbiet tarczy pustynnych połaci nie do przebycia przemierzyłem pieszo,

66) od jednego do drugiego krańca, pnąc się pod górę, to przysiadając, to znów wstając.

67) Wokół mnie dzikie kozice chodzą brunatne, niczym dziewice w szatach powłóczystych,

68) przystają koło mnie wieczorami, jakbym był kozłem $z$ białą łatą na nodze, $z$ długimi zakrzywionymi aż po grzbiet rogami, który ku stokom zmierza.

Podobnie u de Sacy'e go (op. cit. 〈1806〉, t. 3, s. 8; 〈1826〉, t. 2, s. 343): „deux troupes”.

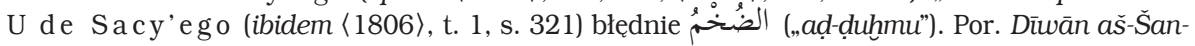
fara, s. 72. - Maḥmūd Muḥammad al - ' ${ }^{\mathrm{A}} \mathrm{m}$ ūd î̀, op. cit., s. 173. 
A. M.

Łono pustyni, co się bez końca rozszerza,

Tak twarde i tak nagie jako grzbiet puklerza,

Nieraz całe ${ }^{45}$ bosymi przemierzyłem stopy;

Gdy ujrzałem nad głową skał podniebne stropy,

Na klęczkach pnąc się, jak pies, wlazłem im na czoło.

Tam dzikie antelopy biegały wokoło,

Białonogie i wełną odziane bogatą,

Jak nadobne dziewice wlekącą się szatą.

I w oczy mi bez trwogi patrzyła gromada,

Bo myślały, że jestem kozieł, wódz ich stada,

Co mu rogi w tak długie piątrzą się ramiona,

Że wznosząc łeb, rogami dostaje ogona,

Albo nimi do skały przyczepia się szczytu

I wisi jako ptaszek w otchłani błękitu. -

Końcówka przekładu A. M. to już właściwie parafraza ostatnich wersów kasydy Aš-Šanfary. Ale i we wcześniejszych partiach tego fragmentu widać stosunkowo dużą dowolność tłumaczenia, jak np. „podniebne stropy” czy ,jak pies, wlazłem im na czoło" albo też motyw białonogich kozic zamiast białej łaty na nodze kozła.

Zestawienie obu przekładów $\mathrm{z}$ oryginałem arabskim potwierdza, jak widać, zacytowaną wcześniej ocenę Bobolewskiego. U Mickiewicza zauważalne jest dążenie do dość szczegółowego odwzorowania struktury wierszowo-tekstowej, tak by jednemu hemistychowi arabskiemu odpowiadał, w miarę możliwości, jeden wers polski. Potwierdza to arytmetyka: 35 dwudzielnych wersów arabskich (70 hemistychów) zostało oddanych 76 wersami tłumaczenia. Tymczasem Spitznagel potrzebował aż 92 wersów. Tak dużą różnicę trudno uzasadnić samym tylko wyborem krótszego formatu wersowego (11-zgłoskowiec). Wynika ona także $z$ większej niż u Mickiewicza tendencji do dowolnego rozbudowywania wattków utworu. Dobrym przykładem jest tłumaczenie wersów 14-24, gdzie 22 hemistychom arabskim odpowiada 20 linijek u Mickiewicza i aż 33 u Spitznagla.

Tym bardziej zastanawiać musi, dlaczego w wersji Spitznagla pominięte zostały zupełnie wersy 8-9 oryginału arabskiego - ważny w końcu fragment tekstu, w którym Aš-Šanfarā chełpi się swoją powściagliwością, opanowaniem i szczodrością. Powstaje pytanie, czy nie był to zabieg zamierzony, podyktowany tym, iż chełpliwość i zarozumiałość nie pasowały do kreślonego przez tłumacza wizerunku bohatera. Jeśli tak, potwierdzałoby to przypuszczenia Bobolewskiego, który starając się dociec przyczyn zarzutu Słowackiego, iż Aš-Šanfarā w przekładzie Mickiewicza „stracił moc zupełnie, a nawet przybrał jakąs odrazy pełną postać”, pisał co następuje:

W fragmencie Spitznagla bohater jest liryczniejszy, nieszczęśliwszy [...], bohater zaś Mickiewicza, szczególniej w pierwszej części utworu, łatwo odnosi zwycięstwa i pogardliwie się ustosunkowuje do

45 W opracowanym przez Zgorzelskiego Wyborze poezyj Mickiewicza wyraz „całe”, prawdopodobnie na skutek błędu drukarskiego, został pominięty. W innych edycjach dzieł wieszcza wers jest kompletny. Zob. np. jedno z najstarszych wydań: Poezje Adama Mickiewicza. T. 5. Poznań 1829 (z dopiskiem: „własność autora” na stronie tytułowej), s. 51. 
wszystkiego (różnica np. stosunku do zwierząt, nowych towarzyszy), monolog więc jego ma pewien odcień samochwalstwa. Czy to jednak miał Słowacki na myśli, mówiąc o „odrazie”?46

W tym kontekście należy podkreślić, że „samochwalstwo” w staroarabskiej poezji było zjawiskiem częstym i wcale nie musiało budzić niesmaku lub dyskredytować poety. Autopanegiryk (ar. ,fahr") był wręcz jednym $z$ uznanych gatunków lirycznych - obok elegii (ar. „rit $\bar{a}^{\text {’”) }}$, satyry (ar. hiğ $\bar{a}^{\urcorner}$) czy też właściwego panegiryku (ar. „madīh").

Podmiot liryczny w arabskiej poezji okresu przedmuzułmańskiego to przeważnie człowiek pustyni, Beduin zahartowany w wędrówkach po odludnych bezkresach, dla którego dzielność, waleczność, duma i honor stanowią cnoty najważniejsze. Ale jednocześnie jest to postać wrażliwa, czuła na piękno, a nawet sentymentalna. Natomiast „poeta-rozbójnik”, jak Aš-Šanfarā i jemu podobni, to oprócz tego nieustraszony wojownik o niepospolitych, nadludzkich nieraz cechach, twardy, nie znający litości dla tych, od których doznał krzywdy. Sama Lämiyyat al- ${ }^{c}$ Arab charakteryzuje się językiem oszczędnym, skondensowanym, a zarazem niezwykle emocjonalnym. Według Imīla Badīa Ya ${ }^{\jmath}$ quba, edytora antologii poezji Aš-Šanfary, szczerość wyrażanych emocji, drobiazgowość obrazowania, piękno opisu i zwięzłość stylu czynia z tego utworu - jak to ują - „perłę pośród arabskich kasyd” ${ }^{47}$. Być może, tu właśnie kryje się powód, dla którego już wiele wieków temu ów wiersz uhonorowano mianem „kasydy Arabów”.

W obu zanalizowanych tu przekładach polskich Aš-Šanfarā został w jakimś stopniu zaadaptowany do ideału bohatera romantycznego i zarazem nieco uwznioślony. Jednak tłumaczenie Mickiewicza - abstrahując od tego, że w przeciwieństwie do Spitznaglowego jest ono kompletne - okazuje się zdecydowanie bliższe oryginalowi tak pod względem struktury wierszowej, jak i pod względem stopnia zgodności z tekstem arabskim. Dużo lepiej oddaje też ducha i atmosferę kasydy. Jak można sądzić, istotna w tym zasługa Józefa Sękowskiego, którego znajomość arabskiego oraz orientalistyczna wiedza i doświadczenie $\mathrm{z}$ pewnością wyraźnie przewyższały arabistyczne umiejętności Spitznagla. Wniosek taki da się wysnuć choćby na podstawie widocznej u Mickiewicza dbałości o zachowanie jak najściślejszej proporcji na poziomie wierszowania, gdzie jednemu dwudzielnemu wersowi arabskiemu odpowiadaja przeważnie dwa wersy polskie. Zadania tego nie ułatwia bowiem sporządzone tekstem ciagłym prozą tłumaczenie francuskie, w którym zdania nie zawsze pokrywają się $z$ wersami.

Biorąc te stwierdzenia pod uwagę, opinię wyrażoną przez Wacława Derejczyka: „Góruje jednak Spitznagel nad Mickiewiczem większą dokładnością w trzymaniu się tekstu pierwowzoru" ${ }^{48}$, traktować trzeba jako absolutnie nieuzasadnioną. Stanowi ona, jak można przypuszczać, przejaw ciagle pokutującej wiary w to, iż - wobec faktu, że Mickiewicz nie znał arabskiego - ukończenie przez Spitznagla 3-letnich studiów orientalistycznych samo przez sie jest gwarantem poprawności i wierności tłumaczenia kasydy. 


\section{ANEKS ${ }^{49}$}

Enfans de ma mère, préparez-vous à partir, et hâtez le pas de vos montures: pour moi, je vais chercher une autre société que celle de votre famille. Déjà toutes choses sont prêtes: l'astre des nuits brille de son éclat, les chameaux sont sanglés, la selle est placée sur leur dos: rien n'arrête plus votre départ.

Il est sur la terre une retraite éloignée, où l'homme généreux peut être à l'abri des insultes; un asyle solitaire, prêt à recevoir quiconque veut se soustraire à la haine des siens. Jamais, non, jamais il ne se trouvera à l'étroit sur la terre, l'homme prudent, et qui sait employer les heures de la nuit à courir après l'objet de ses désirs, ou à s'éloigner de ce qui cause sa frayeur. D'autres compagnons me dédommageront de la perte de votre société, un loup endurci à la course, un léopard au poil ras, une hyène à l'épaisse crinière. En leur compagnie, on ne craint point de voir trahir son secret; le malheureux qui a commis une faiblesse, n'appréhend point de se voir lâchement abandonné en punition de sa faute. Tous ils repoussent les insultes, tous ils combattent avec bravoure; aucun d'eux cependant n'égale l'intrépidité avec laquelle je m'élance au premier aspect de l'ennemi. Mais quand il s'agit d'étendre la main pour partager les alimens, alors que le plus lâche est le plus diligent, je ne les devance plus en vîtesse. C'est l'effet de cette générosité par laquelle je m'élève au-dessus d'eux; celui qui cherche à se distinguer ainsi a droit au premier rang. Je supporterai sans peine la perte de ces compagnons que les bienfaits mêmes ne peuvent subjuguer, et dont le voisinage ne procure aucune agréable diversion. Et je ne m'apercevrai pas de cette perte, pourvu que ces trois autres ne m'abandonnent point, un cœur intrépide, un glaive étincelant, un arc aussi long que robuste qui rende un son éclatant, du nombre de ces arcs polis, et forts en même temps, dont le mérite soit relevé par la beauté des courroies et du baudrier auquel il est suspendu; qui gémit à l'instant où la flèche s'échappe, et semble imiter les cris et les hurlements d'une mère accablée d'infortune, à laquelle le sort a ravi ses enfans.

Je ne suis pas de ces gens incapables de supporter la soif, qui, en menant leurs troupeaux à la pâture, éloignent les petits de leurs mères pour épargner le lait, tandis que celles - ci paissent librement. Je ne suis pas non plus du nombre de ces hommes pusillanimes et poltrons, qui ne s'éloignent jamais de la compagnie de leurs femmes, et délibèrent avec elles sur toutes leurs démarches; de ces hommes qu'un rien étonne, aussi timides que l'autruche, dont le cœur palpitant semble un passereau qui s'élève et s'abaisse tour-à-tour à l'aide de ses ailes; rebut de leurs familles, lâches casaniers, qui passent tout leur temps à causer d'amourettes avec les femmes, et que l'on voit à tous moments du jour parfumés et fardés. Je ne suis pas de ces hommes faibles et petits, dont les défauts ne sont rachetés par aucune vertu, incapables de tout, qui n'étant protégés par aucune arme, prennent l'épouvante à la moindre menace; de ces âmes sans énergie que les ténèbres saisissent d'effroi, quand leur robuste et agile monture entre dans une solitude affreuse qui n'est propre qu'à égarer le voyageur. Quand mes pieds rencontrent une terre dure et semée de cailloux, ils en tirent des étincelles et les font voler en pièces. Je sais supporter la faim avec une constance généreuse, je fais semblant de ne pas la sentir; j'en détourne ma pensée et je l'oublie entièrement. Je dévore la poussière de la terre sèche, et sans aucune humidité, de peur que la faim ne s'imagine avoir quelque avantage sur moi, et ne se vante de m'avoir vaincu. Si la crainte d'essuyer quelque outrage ne m'avoit fait embrasser cette vie penible et errante, tout ce que l'on peut désirer pour appaiser la faim ou la soif, ne se trouveroit que chez moi; mais mon âme généreuse, qui ne peut souffrir aucune insulte, se sépareroit de moi, si je ne m'éloignois promptement. Mes entrailles, tourmentées de la faim, se tortillent et se resserrent sur elles-mêmes, comme les fils torts par la main ferme et adroite d'une habile fileuse.

Je sors dès le matin, n'ayant pris qu'une légère nourriture, tel qu'un loup aux poils grisâtres, qu'une solitude a conduit à une autre solitude, et qui, pressé de la faim, se met en course dès la pointe du jour avec la rapidité du vent: dévoré par le besoin, il se jette dans le fond des vallées et précipite sa marche; fatigué de chercher en vain dans des lieux où il ne trouve aucune proie, il pousse des hurlements auxquels répondent bientôt ses semblables, des loups maigres comme lui, décharnés, dont le visage porte l'empreinte de la vieillesse; on diroit, à la rapidité de leurs mouvements, que ce sont les flèches

49 Przedstawiamy tu francuskie dosłowne tłumaczenie kasydy Aš-Šanfary z pierwszego wydania Chrestomathie arabe de S a cy' e go (Paris 1806). Różni się ono w kilku miejscach od tego, które zamieszczone zostało w drugiej edycji dzieła, a później opublikowane również przez Pila ta na łamach „Pamiętnika Towarzystwa Literackiego imienia Adama Mickiewicza” (1889, s. 259-263). 
qu'agite dans ses mains un homme qui les mêle pour tirer au sort, ou que le chef d'un jeune essaim mis en liberté hâte le vol de la troupe qui le suit, vers les bâtons qu'a placés, pour les recevoir, dans un endroit élevé, l'homme qui s'occupe à recueillir le produit du travail des abeilles. Ces loups ouvrent une large gueule; leurs mâchoires écartées ressemblent aux deux parties d'une pièce de bois que l'on a fendue; ils ont un aspect affreux et terrible. Aux hurlements de ce loup, les autres répondent par des hurlements dont retentissent au loin les déserts; on les prendroit pour autant de mères éplorées, dont les cris déchirans se font entendre du sommet d'une colline élevée. A ses cris succède le silence, et le silence succède à leurs cris; toujours constans à imiter son exemple, ils se consolent de la faim qui les dévore, par celle qu'endure celui-là, et leurs tourments servent aussi à soulager sa douleur. Se plaint-il, ils font entendre leurs plaintes; s'il renonce à des plaintes superflues, les autres y renoncent aussi; et certes, là où les plaintes ne servent de rien, la patience est de beaucoup préférable. Il retourne sur ses pas, et les autres retournent pareillement sur leurs pas: ils précipitent leur course, et quoique pressés par la violence de la faim, ils cachent les maux qu'ils endurent sous une bonne contenance.

Les kata qui volent en troupe vers une citerne, en faisant retentir l'air du bruit de leurs aîles, ne boivent que les restes des eaux que j'ai troublées. Nous courions en même temps pour apaiser notre soif; nous nous hâtions, à l'envi, d'atteindre cet objet de nos désirs: ils déploient toutes leurs forces, tandis que, sans me presser, je les devance lentement, et je semble être le chef de leur troupe. Déjà je les ai quittés, et je me suis retiré, après avoir étanché ma soif: épuisés de fatigue, ils tombent avec précipitation sur les bords humides de la citerne, et plongent dans la fange le cou et le jabot. Le bruit qu'ils font tout à l'entour deautour de cette mare, est comme celui d'une troupe de voyageurs au moment où leur caravane s'arrête pour camper. Ils accourent de toutes parts vers la citerne: elle réunit vers un centre commun leurs troupes éparses, de même que les troupeaux d'un campement d'Arabes se réunissent autour d'un abreuvoir. Ils boivent avec précipitation, et, reprenant leur vol, ils partent aussitôt, semblables, au moment où les premiers rayons du jour éclairent leur retraite, à une caravane de la tribu d'Ohadha qui précipite son départ.

Lorsque je prends la terre pour mon lit, j'étends sur sa surface un dos bossu que soulèvent des vertèbres saillantes et desséchées, et un bras décharné, dont toutes les articulations semblent être autant de dés jetés par un joueur, qui sont tiennent debout devant lui.

Si les destins malins de la guerre se plaignent aujourd'hui que Schanfari échappé à leurs coups, assez long-temps ils ont joui de son malheur. Il a été en proie à toutes les injustices qui se sont partagé sa chair comme celle d'un chameau dont les portions sont tirées au sort; et toutes les fois que quelque malheur est survenu, il en a toujours été la première victime. Si par hasard le sort malin sembloit fermer ses yeux vigilants, dans son sommeil même ses yeux s'ouvroient, et s'empressoient de le fraper de quelque nouveau malheur. Les soucis, ses compagnons assidus, n'ont cessé de se succéder avec autant et plus d'exactitude que le retour régulier des accès d'une fièvre quarte. Lorsqu'ils approchoient, je les éloignois de moi; mais ils revenoient, et fondoient sur moi de toute part.

Si tu me vois, semblable à l'animal qui vit au milieu des sables, me montrer au grand jour, malgré ma délicatesse, les pieds nuds et dépourvus de chaussure, sache que je suis un homme dévoué à la patience: elle est la cuirasse sous laquelle je couvre un cœur de lion, et la fermeté d'âme me tient lieu de sandales. Tantôt je manque de tout, tantôt je suis dans l'abondance: car celui-là est véritablement riche qui ne craint point l'exil, et qui n'épargne point sa vie. Le besoin et l'indigence ne m'arrachent aucun signe d'impatience, et les richesses ne me rendent point insolent. Ma sagesse n'est point le jouet des passions insensées: on ne me voit point rechercher les bruits défavorables que seme la renommée, pour ternir, par des rapports malins, la réputation d'autrui.

Combien de fois, pendant une nuit rigoureuse où le chasseur brûloit, pour se chauffer, et son arc et ses flèches, son unique trésor, je n'ai pas craint de voyager malgré l'épaisseur des ténèbres et la pluie, n'ayant pour toute compagnie que la faim, la froid, la crainte et les alarmes! J'ai rendu des femmes veuves et des enfans orphelins, et je suis revenu comme j'étois parti, tandis que la nuit conservoit encore toute son obscurité. Au matin qui la suivoit, pendant que j'étois parti, tandis que la nuit conservoit encore toute son obscurité. Au matin qui la suivoit, pendant que j'étois tranquillement assis à Gomaïsa, deux troupes causoient ensemble à mon sujet: nos chiens, disoient-ils, ont aboyé cette nuit; nous nous sommes demandé à nous-mêmes: ne seroit-ce point un loup qui erre à la faveur des ténèbres, ou une jeune hyène! Mais, après un instant de bruit, ils se sont rendormis, et alors nous nous sommes tranquillisés en disant: c'est sans doute un milan, ou peut-être un épervier, qui a eu une frayeur pas- 
sagère. Si c'est un génie malin qui a passé par ici, certes il nous a fait un grand mal par sa visite nocturne; si c'est un homme...; mais un homme ne peut pas faire tant de ravages.

Pendant les jours brûlans de la canicule, où les vapeurs formées par l'ardeur du soleil sont en fusion, où les reptiles ne pouvant supporter sa violence s'agitent sur le sable brûlant, j'ai exposé hardiment mon visage à tous ses feux, sans qu'aucun voile me couvrît, et n'ayant pour tout abri contre sa fureur, qu'une toile déchirée, et une longue chevelure, qui, agitée par le vent, se séparoit en touffes épaisses, dans laquelle le peigne n'avoit point passé, qui n'avoit point été, depuis long-temps, ni parfumée, ni purgée de vermine, enduite d'une crasse épaisse, sur laquelle une année entière avoit passé sans qu'elle eût été lavée et nettoyée.

Combien de fois n'ai-je pas traversé, à pied, des déserts immenses, aussi nuds que le dos d'un bouclier, qui n'avoient point accoutumé de sentir le pied des voyageurs! J'en ai parcouru toute l'étendue d'une extrémité jusqu'à l'autre, et je me suis traîné jusqu'au sommet d'une hauteur inaccessible, que j'ai gravie tantôt debout et tantôt assis, comme un chien. Autour de moi rôdoient de noirs bouquetins que l'on eût pris, à leurs longs poils, pour de jeunes filles vêtues d'une robe traînante: ils s'arrêtoient autour de moi sur le soir, et sembloient me prendre pour un grand chamois tacheté de blanc, aux jambes torses, qui gagnoit le penchant de la colline.

Abstract

PAWEL SIWIEC Jagiellonian University, Cracow

\section{“SZANFARY" ONCE AGAIN ON ADAM MICKIEWICZ'S AND LUDWIK SPITZNAGEL'S TRANS-} LATIONS

Towards the end of 1820s there appeared two independent Polish translations of a famous qasida Lammiyyat al ${ }^{-}$Arab ascribed to a legendary "brigand-poet" named Aš-Šanfarā, one of which by Adam Mickiewicz and the other, unfinished, by Ludwik Spitznagel, a young Orientalist, poet, and Juliusz Słowacki's friend. The two translations competed with each other from the beginning of their composition. Their artistic values were compared and their degree of adequacy to the French philological translation by Silvestre de Sacy evaluated. Mickiewicz's version was reproached for being a relay translation based on the French text, while Spitznagel, passed as an excellent expert in Eastern languages, was thought to have translated directly from Arabic.

To date, no attempt has been made to meticulously compare both translations in respect of the Arabic original. The paper aims to complete the shortcoming. 